\title{
Teacher Turnover, Teacher Shortages, and the Organization of Schools
}

Richard Ingersoll

University of Pennsylvania, rmi@upenn.edu

Follow this and additional works at: https://repository.upenn.edu/cpre_researchreports

Part of the Educational Administration and Supervision Commons, Education Economics Commons, Social and Philosophical Foundations of Education Commons, and the Teacher Education and Professional Development Commons

\section{Recommended Citation}

Ingersoll, Richard. (2001). Teacher Turnover, Teacher Shortages, and the Organization of Schools. CPRE Research Reports.

Retrieved from https://repository.upenn.edu/cpre_researchreports/12

View on the CPRE website.

This paper is posted at ScholarlyCommons. https://repository.upenn.edu/cpre_researchreports/12

For more information, please contact repository@pobox.upenn.edu. 


\title{
Teacher Turnover, Teacher Shortages, and the Organization of Schools
}

\begin{abstract}
Contemporary educational theory holds that one of the pivotal causes of inadequate school performance is the inability of schools to adequately staff classrooms with qualified teachers. Contemporary theory also holds that these staffing problems are primarily due to shortages of teachers, which, in turn, are primarily due to recent increases in teacher retirements and student enrollments. This analysis investigates the possibility that there are other factors that might have an impact on teacher turnover levels, and, in turn, the staffing problems of schools, factors rooted in the organizational characteristics and conditions of schools. The data utilized in this investigation are from the Schools and Staffing Survey and its supplement, the Teacher Followup Survey, a large, comprehensive, nationally representative survey of teachers and schools conducted by the National Center for Education Statistics. The results of this analysis show that, net of teacher effects, there are significant effects of school characteristics and organizational conditions on teacher turnover which have largely been overlooked by previous research. For example, the data show that while high-poverty public schools have moderately higher rates, contrary to conventional wisdom, neither larger schools, nor public schools in large school districts, nor urban public schools have especially high rates of teacher turnover. In contrast, small private schools stand out for their high rates of turnover. Moreover, the data show, again contrary to popular wisdom, that the amount of turnover accounted for by retirement is relatively minor, especially when compared to that resulting from two related causes - teacher job dissatisfaction and teachers pursuing other jobs. The data show that, in particular, low salaries, inadequate support from the school administration, student discipline problems, and limited faculty input into school decision-making all contribute to higher rates of turnover, after controlling for the characteristics of both teachers and schools. The results of this investigation suggest that school staffing problems are neither synonymous with, nor primarily due to, teacher shortages in the conventional sense of a deficit in the supply of teachers. Rather, this study suggests that school staffing problems are primarily due to excess demand resulting from a "revolving door" - where large numbers of teachers depart their jobs for reasons other than retirement. This study also suggests that popular education initiatives, such as teacher recruitment programs, will not solve the staffing problems of such schools if they do not also address the organizational sources of low teacher retention.
\end{abstract}

\section{Disciplines}

Educational Administration and Supervision | Education Economics | Social and Philosophical

Foundations of Education | Teacher Education and Professional Development

\section{Comments}

View on the CPRE website. 


\section{Teacher Turnover, Teacher Shortages, and the Organization of Schools}

Richard M. Ingersoll University of Pennsylvania

January 2001 (Document R-01-1) 


\title{
ctp \\ Center for the Study of Teaching and Policy A National Research Consortium
}

\author{
U N I VERS I T Y O F W A S I N G T O N (lead institution) \\ STANFORD UNIVERSITY \\ TEACHERS COLLEGE/COLUMBIA UNIVERSITY \\ UNIVERSITY OF MICHIGAN \\ UNIVERSITY OF PENNSYLVANIA
}

Other active participants in CTP's research and dissemination program include researchers affiliated with Indiana University, Michigan State University, Pennsylvania State University, the University of California at Santa Barbara, the University of North Carolina, and Education Matters, Inc.

CTP studies the way policies and conditions in schools, districts, states, and the nation shape the quality of teaching and learning in our nation's elementary and secondary schools. The Center pays particular attention to the ways these policies and conditions interact with each other to influence the teaching profession and its practice.

The Center's program of research is carried out in collaboration with various other research organizations, among them other OERI-funded research centers, including the Consortium for Policy Research in Education (CPRE), the Center for Research on Education, Diversity, and Excellence (CREDE), and the Center on English Learning \& Achievement (CELA). The Center is affiliated with a variety of professional and advocacy organizations that represent teachers, teacher educators, state and local policymakers, disciplinary groups, and educational reform interests.

The work reported herein was supported under the Educational Research and Development Centers Program, PR/Award Number R308B970003, as administered by the National Institute on Educational Governance, Finance, Policymaking and Management, Office of Educational Research and Improvement (OERI), U.S. Department of Education. However, the contents do not necessarily represent the positions or policies of the National Institute, OERI, or the U.S. Department of Education, or the endorsement of the federal government.

Versions of this report were presented at the annual meeting of the American Sociological Association, August 1997, and the annual meeting of the American Educational Research Association, April 2000. Thanks are due to Richard Murnane, James Price, Linda Grant, William Finlay, and Mike Knapp for helpful comments on earlier drafts of this report. 


\section{CONTENTS}

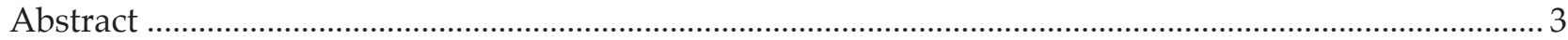

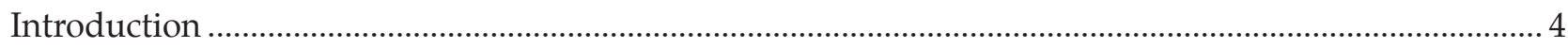

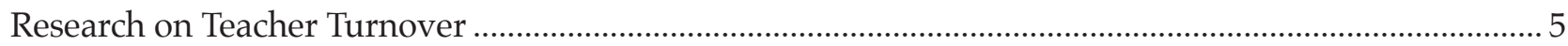

Teacher Turnover, Teacher Shortages, and the Organization of Schools .................................................... 7

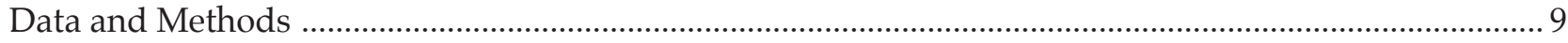

Data

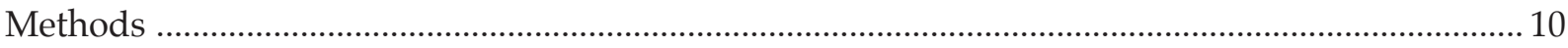

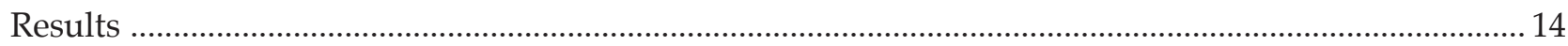

Levels of Turnover and School Staffing Problems ......................................................................... 14

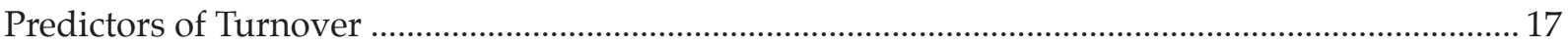

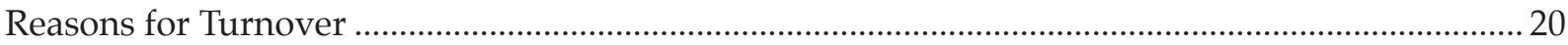

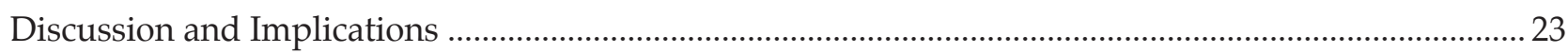

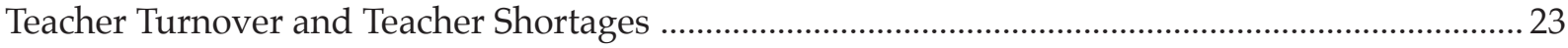

Teacher Turnover, School Community, and School Effectiveness .................................................... 24

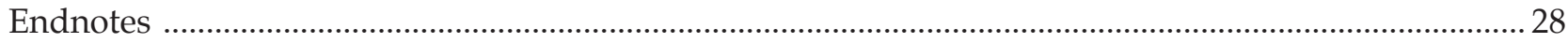

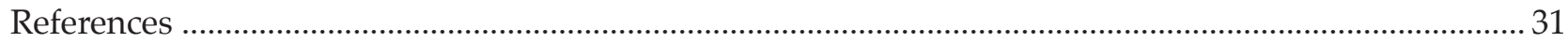





\section{ABSTRACT}

Contemporary educational theory holds that one of the pivotal causes of inadequate school performance is the inability of schools to adequately staff classrooms with qualified teachers. Contemporary theory also holds that these staffing problems are primarily due to shortages of teachers, which, in turn, are primarily due to recent increases in teacher retirements and student enrollments. This analysis investigates the possibility that there are other factors that might have an impact on teacher turnover levels, and, in turn, the staffing problems of schools, factors rooted in the organizational characteristics and conditions of schools. The data utilized in this investigation are from the Schools and Staffing Survey and its supplement, the Teacher Followup Survey, a large, comprehensive, nationally representative survey of teachers and schools conducted by the National Center for Education Statistics. The results of this analysis show that, net of teacher effects, there are significant effects of school characteristics and organizational conditions on teacher turnover which have largely been overlooked by previous research. For example, the data show that while high-poverty public schools have moderately higher rates, contrary to conventional wisdom, neither larger schools, nor public schools in large school districts, nor urban public schools have especially high rates of teacher turnover. In contrast, small private schools stand out for their high rates of turnover. Moreover, the data show, again contrary to popular wisdom, that the amount of turnover accounted for by retirement is relatively minor, especially when compared to that resulting from two related causes - teacher job dissatisfaction and teachers pursuing other jobs. The data show that, in particular, low salaries, inadequate support from the school administration, student discipline problems, and limited faculty input into school decision-making all contribute to higher rates of turnover, after controlling for the characteristics of both teachers and schools. The results of this investigation suggest that school staffing problems are neither synonymous with, nor primarily due to, teacher shortages in the conventional sense of a deficit in the supply of teachers. Rather, this study suggests that school staffing problems are primarily due to excess demand resulting from a "revolving door" where large numbers of teachers depart their jobs for reasons other than retirement. This study also suggests that popular education initiatives, such as teacher recruitment programs, will not solve the staffing problems of such schools if they do not also address the organizational sources of low teacher retention. 


\section{INTRODUCTION}

Few educational problems have received more attention in recent times than the failure to ensure that elementary and secondary classrooms are all staffed with qualified teachers. In the early 1980s, a series of highly publicized reports began to focus national attention on the coming possibility of severe teacher shortages in elementary and secondary schools (e.g., Darling-Hammond, 1984; National Commission on Excellence in Education, 1983; for reviews of this debate, see Boe \& Gilford, 1992; Haggstrom et al., 1988; National Academy of Sciences, 1987). These studies predicted a dramatic increase in the demand for new teachers primarily resulting from converging demographic trends: increasing student enrollments and increasing teacher attrition due to a "graying" teacher force. These reports held that subsequent shortfalls of teachers would, in turn, force many school systems to resort to lowering standards to fill teaching openings, inevitably resulting in high levels of underqualified teachers and lower school performance. The inability of schools to adequately staff classrooms with qualified teachers (hereafter referred to as school staffing problems) has since been cast as a major educational problem, received widespread coverage in the national media, been the target of a growing number of reform and policy initiatives, and been the subject of a substantial body of empirical research (for a review of this issue, see National Commission on Teaching, 1997).

The dominant policy response to school staffing problems has been to attempt to augment the quantity of teacher supply. Over the past decade, a wide range of initiatives has been implemented to recruit new candidates into teaching. Some programs, such as "Troops-to-Teachers," are designed to entice professionals into midcareer changes to teaching. Others, such as "Teach for America," are Peace Corpslike programs designed to lure the "best and brightest" into teaching. There are also a wide range of alternative licensing programs, whereby college graduates can postpone formal education training, obtain an emergency teaching license, and begin teaching immediately (Clinton, 1999; Feistritzer, 1997; Kopp, 1992).

Concern over shortages has also provided the impetus for empirical research on teacher supply and demand. In particular, over the past two decades a substantial body of empirical analysis has focused on teacher turnover - the departure of teachers from their teaching jobs (e.g., Grissmer \& Kirby, 1987, 1992, 1997; Heyns, 1998; Murnane, 1981, 1987; Murnane, Singer, \& Willett, 1998). This article also examines teacher turnover, but from a different perspective than most previous empirical research on this topic. Although problems of teacher staffing and attrition have become among the most important policy issues facing schools and the subject of much research, there has been very little research or commentary from a sociological perspective. In particular, few studies have examined the effects of the organizational conditions of the schools in which turnover and staffing problems are embedded. Existing empirical research has generally sought to explain teacher turnover as a function of the characteristics of individul teachers. Moreover, most research has focused on narrow subsets of the total turnover and inter-organizational mobility of teachers. This analysis attempts to extend existing theory and research by adopting a previously under-emphasized perspective: the examination of teacher turnover as an organizational phenomenon. This analysis' theoretical perspective, drawn from the sociology of organizations, occupations, and work, is that teacher turnover and, in turn, school staffing problems cannot be fully understood without closely examining the characteristics of the organizations that employ teachers, and also examining turnover at the level of the organization. My objective is two-fold: to first briefly document the role of teacher turnover in the staffing problems of schools and then to closely examine the role of school characteristics and organizational conditions in teacher turnover. 
In brief, the results of the analysis show that teacher turnover is a significant phenomenon and a dominant factor behind the demand for new teachers and the difficulties schools encounter adequately staffing classrooms with qualified teachers. Consistent with prior empirical research, my analysis indicates that teacher characteristics, such as specialty field and age, account for a significant amount of turnover. But, net of teacher effects, there are also significant effects of school characteristics and organizational conditions on turnover that have largely been overlooked by previous research. The data show that while high-poverty public schools have moderately higher rates, neither larger schools, nor public schools in large school districts, nor urban public schools have especially high rates of teacher turnover. In contrast, small private schools stand out for their high rates of turnover.

Moreover, the data show that while it is true that teacher retirements are increasing, the overall amount of turnover accounted for by retirement is relatively minor when compared to that resulting from other causes such as teacher job dissatisfaction and teachers pursuing better jobs or other careers. The data show that, in particular, low salaries, inadequate support from the school administration, student discipline problems, and limited faculty input into school decision-making all contribute to higher rates of turnover, after controlling for the characteristics of both teachers and schools.

These findings have important implications for both theory and policy concerning school staffing problems. As mentioned, existing theory holds that teacher shortages, largely due to inexorable, macro, demographic trends, are the primary factor behind staffing problems. In turn, the dominant policy response has been to attempt to increase the quantity of teachers supplied through various recruitment strategies. In contrast, this analysis suggests that school staffing problems are neither synonymous with, nor primarily due to, teacher shortages in the conventional sense of a lack or deficit of qualified candidates. Rather, the data suggest that school staffing problems are primarily due to excess demand resulting from a "revolving door," where large numbers of teachers depart their jobs for reasons other than retirement. It also suggests that teacher recruitment programs alone will not solve the staffing problems of schools if they do not also address the organizational sources of low retention.

This analysis also has implications for the literature on school community and school effectiveness. Educational sociologists, in particular, have long held that the presence of a sense of community and cohesion among families, teachers, and students is important for the success of schools (e.g., Durkheim 1925/1961; Waller, 1932; Parsons, 1959; Grant, 1988; Rosenholtz, 1989). In general, large urban, high-poverty public schools are often cited as those least likely to be characterized by a tight-knit sense of cohesion, while small private schools are often cited as those most likely to be so characterized (e.g., Bryk et al., 1990; Coleman \& Hoffer, 1987). This analysis reveals that the latter have far higher rates of teacher turnover than the former. The article closes by offering a hypothesis to account for these counterintuitive findings.

Below, I first review in more detail the existing empirical research on teacher turnover and what I believe are its limitations.

\section{RESEARCH ON TEACHER TURNOVER}

Over the past two decades there has been substantial empirical research focused on determining which kinds of teachers are more prone to leave teaching and why (e.g., Bobbitt et al., 1994; Chapman \& Green, 1986; Chapman \& Hutcheson, 1982; Grissmer \& Kirby, 1987, 1992, 1997; Hafner \& Owings, 1991; Haggstrom et al., 1988; Heyns, 1988; Marso \& Pigge, 1991; Miech \& Elder, 1996; Murnane, 1981, 1987; Murnane 
et al., 1991; Murnane, Singer, \& Willett, 1988; Rumberger 1987; Schlecty \& Vance, 1981, 1983; Weiss \& Boyd, 1990). This research shows teacher turnover is strongly correlated with the individual characteristics of teachers. Among the most important findings has been that teacher turnover is strongly affected by academic field. Although the data have been inconsistent at times, special education, mathematics, and science are typically found to be the fields of highest turnover (Boe, Bobbitt, \& Cook, 1997; Grissmer \& Kirby, 1992; Murnane et al., 1991; Rumberger, 1987).

Another important finding has been that teachers' decisions whether to stay or leave the teaching profession are highly influenced by their age. The relationship between teachers' age (or experience, in some analyses) and their turnover has been found to follow a U-shaped curve. Although there is some disagreement as to why this is the case, researchers have consistently found that younger teachers have very high rates of departure. Subsequently, as those remaining "settle in," turnover rates decline through the mid-career period and, finally, rise again in the retirement years (e.g., Bobbitt et al., 1994; Boe et al., 1998; Grissmer \& Kirby, 1987, 1992, 1997; Hafner \& Owings, 1991; Murnane, Singer, \& Willett, 1988). Moreover, because the distribution of age in the teaching force is skewed upward-older teachers significantly outnumber younger teachers - many analysts have concluded that retirement due to a rapidly "graying" teaching workforce is the most significant factor behind teacher turnover, teacher shortages, and school staffing problems (e.g., Grissmer \& Kirby, 1997).

Such research has provided a great deal of insight into the sources of teacher turnover; however, there are two important limitations to existing empirical studies. First, most of this empirical research has focused on assessing whether particular kinds of teachers are more or less likely to depart teaching and has generally sought to explain teacher turnover as a function of the characteristics of individual teachers. As noted by some (e.g., Barro, 1992; Boe \& Gilford, 1992), researchers have focused far less frequently on explaining teacher turnover as a function of the characteristics of schools. To be sure, a number of analysts have compared or controlled for turnover differences across different types of schools (e.g., Bacharach \& Bamberger, 1990; Bobbitt et al., 1994; Boe et al., 1998; Heyns, 1988; Miech \& Elder, 1996; Murnane, 1981; Sclan, 1993; Theobald, 1990). However, few have examined in detail which characteristics and conditions of schools are related to teacher turnover, especially with large-scale or representative data. ${ }^{1}$ Although it is widely believed, for example, that urban, highpoverty public schools have very high levels of teacher turnover (e.g., DarlingHammond \& Green, 1994; Kozol, 1991; Oakes, 1990; Rosenholtz, 1985), there have been few atempts to rigorously test this assumption with nationally representative data or to examine which aspects of these schools contribute to teacher turnover.

Additionally, much of the empirical research has tended to emphasize only one component of the overall flow of teachers from schools: those who leave the occupation of teaching altogether, often (and hereafter) referred to as teacher attrition. Researchers have often de-emphasized the other major component of turnover: those who transfer or move to different teaching jobs in other schools, often (and hereafter) referred to as teacher migration. To be sure, a number of analysts have examined levels and variations in cross-school teacher migration (e.g., Boe, et al., 1998; Grissmer \& Kirby, 1987, 1992; Murnane, 1981; Rollefson \& Broughman, 1995). However, many assume migration is a less significant form of turnover because it does not increase or decrease the overall supply of teachers, as do retirements and career changes, and thus, does not contribute to overall systemic shortages.

These are important limitations. As a result of an emphasis on individual-level factors, much less is known of whether teacher turnover is disproportionately concentrated in particular types of schools and, also, which aspects of schools affect turnover. Moreover, little is known of how the organizational conditions of schools both impact and are impacted by turnover. In addition, about half of the overall 
turnover of teachers is migration from one school to another (Ingersoll 1995a). Hence, the research emphasis on attrition has meant that much less is known of the magnitude and causes of the totality of employment instability, turnover, and inter-organizational mobility in schools and their consequences for school staffing problems and teacher shortages. ${ }^{2}$

One reason for these research limitations has been a lack of data, especially at a nationally representative level, on the extent of, types of, and reasons for teacher turnover. For example, some of the best known research on teacher attrition has used single-city or single-state data (e.g, Grissmer \& Kirby, 1992; Murnane, 1981; Murnane et al., 1991; Schlechty \& Vance, 1981, 1983). Besides obvious limits to generalization, another key limitation of such data is that it is difficult to distinguish between teacher attrition and teacher migration to teaching jobs in other cities or states because the latter "leave" the sampling frame.

It was partly in order to address these data shortcomings that the U.S. Department of Education's National Center for Education Statistics (NCES) conducted the Schools and Staffing Survey (SASS) and its supplement, the Teacher Followup Survey (TFS), beginning in the late 1980s. Unlike most previous data sources, this dataset is large, comprehensive, and nationally representative, and includes teacher migration, teacher attrition, the reasons teachers themselves give for their departures, and a wide range of information on the characteristics and conditions of schools.

\section{Teacher TuRnover, Teacher SHORTAGeS, AND the ORGANIZATION OF SCHOOLS}

The objective of this study is to use the SASS/TFS data to examine teacher turnover and school staffing problems as organizational phenomena. My analysis is based upon three general, interrelated premises: (a) employee turnover is important because of its link to the performance and effectiveness of organizations; (b) fully understanding turnover requires examining it at the level of the organization; (c) turnover is affected by the character and conditions of the organizations within which employees work. These premises are drawn from the sociology of organizations, occupations, and work, and the empirical literature on employee turnover.

Research on employee turnover is extensive and has examined a very wide variety of aspects of employee stability, turnover, and mobility, with, at times, inconsistent findings (e.g., Price 1977, 1989; Mueller \& Price, 1990; Bluedorn, 1982; Halaby \& Weakliem, 1989; Hom \& Griffeth, 1995; Kalleberg \& Mastekaasa, 1998; March \& Simon, 1958; Mobley, 1982; Steers \& Momday, 1981). ${ }^{3}$ However, consistently running throughout virtually all of this literature is the premise that employee turnover is important because of its link to the performance and effectiveness of organizations. On the one hand, researchers have found that a low level of employee turnover is normal and efficacious in a well-managed organization. Too little turnover of employees is tied to stagnancy in organizations; effective organizations usually both promote and benefit from a limited degree of turnover by eliminating low-caliber performers and bringing in "new blood" to facilitate innovation. On the other hand, a central finding in this literature is that high levels of employee turnover are both cause and efect of dysfunction and low performance in organizations.

Organizational analysts have also noted that the organizational consequences of employee turnover vary among different types of employees and among different types of organizations. Labor process analysts, for instance, have argued that a major issue, from the viewpoint of organizational management, is the extent to which the organization is or is not dependent on particular types of employees and, hence, vulnerable to the disruption caused by their turnover (e.g., Braverman, 1974; Burawoy, 
1979; Edwards, 1979). For just this reason the issue of employee "substitutability," or the ease with which organizations can replace employees, is a central concern in organizational management and a central theme in organizational research. In this perspective, employee turnover is especially consequential in organizations that have uncertain and non-routine technologies and production processes requiring extensive interaction among participants. Such organizations are often unusually dependent upon commitment and cohesion among employees and management and, hence, especially vulnerable to employee turnover (e.g., Burns \& Stalker, 1961; Kanter, 1977; Likert, 1967; Porter, Lawler \& Hackman, 1975; Turner \& Lawrence, 1964; Walton, 1980).

Schools have traditionally been identified as a key example of organizations characterized by an uncertain and non-routine technology and by dependence on commitment and cohesion among members (e.g., Bidwell, 1965; Ingersoll, 1993; Lortie, 1975). Indeed, the presence of a sense of community among families, teachers, and students has long been held by education researchers to be one of the most important indicators and aspects of successful schools (e.g., Durkheim, 1925/1961; Waller, 1932; Parsons, 1959; Grant, 1988; Coleman \& Hoffer, 1987; Kirst, 1989; Rosenholtz, 1989). Hence, from an organizational perspective, high turnover of teachers from schools is of concern not simply because it may be an indicator of sites of potential staffing problems, but because of its relationship to school performance. Moreover, from this perspective, high rates of teacher turnover are of concern not only because they may be an indication of underlying problems in how well schools function, but also because they can be disruptive, in and of themselves, for the quality of school community and performance.

As discussed above, the literature on teacher turnover places much emphasis on the distinction between those leaving the occupation altogether and those moving to teaching jobs in other schols. From the systemic-level perspective, often adopted in this literature, migration is assumed irrelevant. In contrast, the literature on employee turnover rarely notes this distinction. From the organizational-level perspective, often adopted in this literature, employee migration is as relevant as employee attrition. The premise underlying this perspective is that, whether those departing are moving to a similar job in another organization or leaving the occupation altogether, their departures similarly impact and are impacted by the organization.

The third premise underlying this analysis is that turnover is affected by the character and conditions of the organizations within which employees work. A long tradition of research has shown that, in addition to individual and personal characteristics of employees, the overall conditions of workplaces and job sites significantly affect the attachment of employees to the organization (e.g., Price, 1977, 1989; Mueller \& Price, 1990; Bluedorn, 1982; Halaby \& Weakliem, 1989; Hom \& Griffeth, 1995; Kalleberg \& Mastekaasa, 1998; March \& Simon, 1958; Mobley, 1982; Steers \& Momday, 1981). Researchers have found among the most important of these organizational conditions: the compensation structure for employees; the level of administrative support, especially for new employees; the degree of conflict and strife within the organization; and the degree of employee input into and influence over organization policies. This research has found strong links between these kinds of organizational conditions and employee motivation, commitment, and turnover. From this perspective, it is reasonable to expect that these same organizational conditions may also be among the more important factors affecting the rates at which teachers depart particular schools.

This study is drawn from a larger project that examines issues of teacher supply, demand, and quality from an organizational perspective. ${ }^{4}$ In this research report I focus on two objectives. The first is to investigate the role of teacher turnover in the staffing problems of schools. I examine the overall magnitude of both teacher attrition and migration, compare the rates of teacher turnover with those of other occupations, 
and ascertain the portion of the demand for new teachers that is accounted for by turnover. The second objective is to examine the role of school characteristics and oranizational conditions in teacher turnover. I examine whether there are significant differences in levels of teacher turnover at different types of schools and whether organizational conditions in schools account for a significant portion of teacher turnover, after controlling for the characteristics of teachers and schools. While there are many aspects of schools and their organization that may affect teacher turnover, this analysis focuses on a set of four particular organizational conditions in schools, reflecting those discussed above, that have consistently been found to be crucial for employee turnover: the compensation structure for employees; the level of administrative support, especially for new employees; the degree of conflict and strife within the organization; and the degree of employee input into and influence over organization policies. These four conditions are a useful focus because they have also been found to be among the most important aspects of school organization and are "policy amenable" (e.g., Goodlad, 1984; Metz, 1986; Newman, Rutter \& Smith, 1989; Pallas, 1988; Rosenholtz, 1989; Bryk, Lee \& Smith, 1990). This analysis examines the importance of their impact on teacher turnover.

\section{DATA AND METHODS}

Below, I describe in more detail the data source and types of methods, both descriptive and multivariate, to be used in this analysis.

\section{Data}

As indicated, the data for this study come from the National Center for Education Statistics' (NCES) nationally representative Schools and Staffing Survey (SASS) and its supplement, the Teacher Followup Survey (TFS). This is the largest and most comprehensive data source available on the staffing, occupational, and organizational aspects of schools and was specifically designed to remedy the lack of nationally representative data on these issues (Haggstrom et al., 1988; Ingersoll, 1995b).

The U.S. Census Bureau collected the SASS data for NCES from a random sample of schools stratified by state, public/private sector, and school level. Each cycle of SASS includes separate, but linked, questionnaires for administrators and for a random sample of teachers in each school. In addition, one year later, the same schools were again contacted and all those in the original teacher sample who had moved from or left their teaching jobs were given a second questionnaire in order to obtain information on their departures. This latter group, along with a representative sample of those who stayed in their teaching jobs, comprise the TFS. This analysis primarily uses data from the 1991-92 TFS, linked with data from the 1990-91 SASS teacher and administrator questionnaires.

The 1991-92 TFS sample comprises 6,733 teachers (3,343 continuing teachers, 1,428 migrations, and 1,962 attritions). This analysis uses data weighted to compensate for the over- and under-sampling of the complex stratified survey design. Each observation is weighted by the inverse of its probability of selection in order to obtain unbiased estimates of the national population of schools and teachers in the year of the survey. ${ }^{5}$ 
This investigation is unusual in that it does not focus on narrow subsets of turnover and inter-organizational mobility. Unlike most research on teacher turnover, this analysis examines all turnover, including both teacher migration and teacher attrition (hereafter also referred to as total departures, movers and leavers, respectively). Moreover, unlike most research on employee turnover, this analysis examines both voluntary and involuntary turnover (the latter typically includes retirements, layoffs, terminations). ${ }^{6}$ This study does not ignore differences in these subsets; it assesses these different types of flows both together, to capture the totality, and separately, to examine differences. ${ }^{7}$

The analysis is divided into three stages. In the first stage I establish the overall magnitude of teacher turnover and its role in teacher demand and school staffing problems. In the second stage, I conduct an exploratory regression analysis of the effects of teacher characteristics, school characteristics, and organizational conditions on turnover. In the third stage, I follow up with a detailed examination of the reasons teachers give for their departures. Below, I describe these three stages of my analysis.

I first introduce descriptive data to establish recent trends in the overall magnitude of teacher migration, attrition, and retirement, their impact on the demand for new teachers, and their role in the difficulties schools encounter adequately staffing classrooms with qualified teachers. I also establish the extent of variation in turnover across different types of schools and compare these levels to employee turnover in other occupations.

The second stage presents an exploratory multiple regression analysis of the predictors of teacher turnover. The dependent variable-teacher turnover-is a dichotomous variable based on whether each teacher remained with or departed from his or her teaching job. I cumulatively examine three groups of predictors of turnover: teacher characteristics, school characteristics, and organizational conditions. Figure 1 provides definitions for these variables. Table 1 provides mean teacher and school characteristics and conditions associated with the teachers in the sample.

Following previous research on teacher turnover, I include control variables for several characteristics of teachers: race, gender, age, and subject/field of teaching. Because of its U-shaped relationship, I transform age into a three-category set of dummy variables: younger (less than 30), middle-aged (31-50) and older (greater than 50).

Research on school organization has revealed important differences in the organizational structure and behavior of different types of schools (e.g., Bidwell \& Quiroz, 1991; Bryk et al., 1990; Chubb \& Moe, 1990; Coleman \& Hoffer, 1987; Pallas, 1988; Rowan et al., 1991). In order to control for these factors, I include, as independent variables, school characteristics typically found to be important in this literature: school level, size, urbanicity, and sector. In addition to finding important differences between public and private schools, research on school organization has also shown distinct within-sector differences in school organization. In order to explore within-sector differences and whether or not the factors that predict turnover vary between sectors, my analysis first examines turnover for all schools and follows with separate analyses of turnover at both public and private schools. For public schools, I include additional variables for the district size and the level of poverty of the student population. For private schools, I include additional dummy variables for the orientation or affiliation of the school (Catholic, other religious, and nonsectarian). ${ }^{8}$

Finally, and only after controlling for the above teacher and school factors, I focus on the effects of four measures reflecting the four organizational conditions introduced earlier. Unlike most empirical analyses that use either individual teacher's 


\section{Table 1: Means and Standard Deviations for Variables Utilized in Regression Analysis}

\begin{tabular}{lcc} 
& (mean) & (sd) \\
\hline Teacher Characteristics & & \\
Young & .11 & - \\
Old & .09 & - \\
Math/Science & .11 & - \\
Special Education & .10 & - \\
Male & .28 & - \\
Minority & .13 & - \\
School Characteristics & & \\
Private & .24 & - \\
Size & 684 & 492 \\
Rural & .40 & - \\
Suburban & .31 & - \\
Secondary Level & .33 & - \\
District Size (Public only) & 2,320 & 20,694 \\
\% Poverty Enrollment (Public only) & .31 & .26 \\
Catholic (Private only) & .43 & - \\
Other Religious (Private only) & .36 & - \\
Organizational Conditions & & \\
Advanced Salary (\$) & 35,499 & 8,320 \\
Administrative Support & 2.98 & .47 \\
Student Conflict & 1.84 & .44 \\
Faculty Influence & 4.5 & .53 \\
\hline
\end{tabular}

salaries or the school's mean teacher salary, I use the school salary schedule for advanced teachers (those with a MA degree and at least 20 years experience) because it better assesses differences in the organizational-level compensation structure. ${ }^{9}$ For administrative support, I utilize an index of the degree of assistance provided to new teachers, as reported by all teachers. For the degree of conflict and strife within the organization, I use an index of the level of student discipline problems within schools as reported by teachers. For the degree of employee input into and influence over organization policies, I use an index of the degree of faculty classroom control and influence over school policies. In background analyses I also tested other related measures of organizational conditions, such as faculty collegiality/cohesion and administrative support for all teachers. The effects of these were similar to the above four measures, but the relationships were weaker and because of multicollinearity they were dropped from the analysis.

In this stage of the analysis, I use logistic regression to explore whether the likelihood of individual teachers moving from or leaving their teaching jobs is related to the above school-level measures of school characteristics and organizational conditions, while controlling for individual-level characteristics of teachers. Over the past two decades, there has been a growing debate concerning the most appropriate multiple regression method for modeling data, such as those used here, that are collected at more than one level (e.g., Bidwell \& Kasarda, 1980; Pfeffer, 1982; Rowan 
et al., 1991). Recently, a number of statistical packages have been developed specifically for modeling multilevel data. However, currently available versions of these packages, for one reason or another, do not allow non-linear analysis of binomial dependent variables that require inclusion of design weights at multiple levels (e.g., individual and organizational levels). ${ }^{10}$ Because the TFS sample is based on those who departed their teaching jobs and under samples those who did not depart, use of design weights is necessary. Hence, in my analysis of turnover I use regular SASS logistic multiple regression. Practically speaking for this analysis, the primary consequence of using regular logistic regression is that it may produce less-than-precise standard errors for the school-level coefficients.

To provide confidence in my findings, I have conducted two additional analyses. First, I undertook a series of additional background multivariate analyses. SASS/ TFS is a cross-sectional survey which has been conducted three times to date. Since most of the items used in this analysis were included in the first two cycles, I was able to estimate the same models with these independent data sources. Moreover, the first two cycles of SASS provide a separate school-level turnover rate based on school principals' reports of the percentage of their teaching staff that separated from their schools. I also estimated similar models using both ordinary least squares and logistic multiple regression with this school-level measure of turnover as the dependent variable (see Ingersoll, 1995a for a published research report). In all of these analysesdifferent data cycles and with different types of dependent variables-I found the results to be very similar. Notably, my major findings on school and organizational effects, described in the following results section, were confirmed.

Second, I treat the multiple regression stage of my analysis as exploratory and follow it up with a third stage of analysis involving a more in-depth examination of the reasons for teacher turnover using a set of different data items from the TFS. I analyze data drawn from items in the TFS questionnaire that asked teacherrespondents to indicate the reasons (up to three) for their departures from a list in the survey questionnaire. I also analyze data from an additional set of items which asked these respondents to indicate the sources (up to three) of their dissatisfaction, if they had indicated job dissatisfaction as a reason for their turnover. (See Figure 1). Selfreport data such as these are useful because those departing are, of course, often in the best position to know the reasons for their departures. But, such self-report data are also retrospective attributions, subject to bias and, hence, warrant caution in interpretation. Here I utilize the self-report data in conjunction with the prior regression analyses, which utilize school-level data from a larger set of respondents. This allows the analysis to take advantage of the unusual breadth of the SASS/TFS data, while also providing a means of comparison and, hence, checking, the two sets of findings concerning the effect of school characteristics and organizational conditions on turnover.

There is also another advantage of utilizing the two types of data in conjunction. This study does not attempt to provide a comprehensive analysis of all the many factors that may possibly impact the turnover of teachers. Thus, any relationships found between turnover and school or organizational variables could, of course, be partly a result of other unobserved factors not included in the analysis. For instance, turnover in private schools might not be due to school effects, but to teacher selection effects, i.e. those employed in private schools might tend to view teaching as a temporary job prior to embarking on a more permanent career. It is not possible to control for all such factors, but it is possible to further explore these issues by taking a more in-depth look at the reasons teachers themselves give for their turnover-the objective of the third stage of the analysis. This stage separately examines both migration and attrition and both voluntary and involuntary departures and focuses, in particular, on two widely divergent types of schools: small private and urban, highpoverty public schools. 


\section{Figure 1: Definitions of Measures Used in the Analysis}

Teacher Turnover: a dichotomous variable where $1=$ not teaching in same school as last year and $0=$ stayer/currently teaching in same school.

\section{Teacher Characteristics}

- Young: a dichotomous variable where $1=$ teacher less than 30 years of age and $0=$ other teachers.

- Old: a dichotomous variable where $1=$ teacher older than 50 years of age and $0=$ other teachers.

- Math/Science: a dichotomous variable where $1=$ teachers listed by their principals as primarily teaching secondary math or science and $0=$ all other teachers.

- Special Education: a dichotomous variable where $1=$ teachers listed by their principals as primarily teaching elementary or secondary special education and $0=$ other teachers.

- Male: a dichotomous variable where $1=$ male teacher and $0=$ female teacher.

- Minority: a dichotomous variable where $1=$ nonwhite teacher and $0=$ other teachers.

\section{School Characteristics}

- Private: a dichotomous variable where $1=$ private and $0=$ public.

- Size: student enrollment of school.

- Rural: a dichotomous variable where $1=$ rural and $0=$ suburban or urban.

- Suburban: a dichotomous variable where $1=$ suburban and $0=$ rural or urban.

- Secondary Level: a dichotomous variable where $1=$ junior or senior secondary and $0=$ elementary or middle or combined (K-12).

\section{Public schools}

- District Size: student enrollment of school district.

- Poverty Enrollment: percentage of students receiving the federal free or reduced-price lunch program for students from families below poverty level. Not available for private schools.

\section{Private schools}

- Catholic: a dichotomous variable for school orientation where $1=$ Catholic and $0=$ other religious or nonsectarian.

- Other Religious: a dichotomous variable for school orientation where $1=$ Other Religious and $0=$ Catholic or nonsectarian.

\section{Organizational Conditions}

- Advanced Salary: normal yearly salary for teacher with a MA and 20 years of experience, as reported by school administrators. This measure excludes private school teachers whose effort is contributed as a free service.

- Administrative Support: on a scale of $1=$ strongly disagree to $4=$ strongly agree, the school mean of the amount of agreement of all teachers with the statement "this school is effective in assisting new teachers" for four related items: student discipline, instructional methods, curriculum, and adjusting to the school environment.

- Student Discipline Problems: on a scale of $1=$ not a problem to $4=$ serious, the school mean of teachers' reports for eight kinds of student discipline problems: disruptive behavior, absenteeism, physical conflicts among students, robbery, vandalism, weapon possession, physical abuse of teachers, verbal abuse of teachers.

- Faculty Influence: on a scale of $1=$ none to $6=$ a great deal, the school mean of faculty control and influence over 10 areas: selecting textbooks and other instructional materials; selecting content, topics and skills to be taught; selecting teaching techniques; determining the amount of homework to be assigned; disciplining students; curriculum; ability grouping; school discipline policy; content of in-service programs.

Factor analysis (with varimax rotation method) was used to develop the indices of student discipline problems and faculty influence. Item loadings of .4 were considered necessary for inclusion in a factor. No items loaded on more than one factor. Each factor had high internal consistency $(a>.7)$. The measures of student discipline problems, faculty influence and administrative support are all school means of the reports of the total SASS teacher sample for each school and not limited to the reports of those in the smaller TFS sample. Intercorrelations among the four conditions were moderate to low $(<.44)$

Reasons for Turnover (Table 5)

Teachers could list up to 3 choices from a list of 12 reasons for their departures. I grouped the 12 reasons into 5 categories, as follows:

- School Staffing Action: reduction-in-force; lay-off; school closing; reassignment.

- Dissatisfaction: dissatisfied with teaching as a career; dissatisfied with the school; for better salary or benefits.

- Personal: family or personal move; pregnancy/child rearing; health; other family or personal reason.

- To Pursue other Job: to pursue another career; to take courses to improve career opportunities in or outside the field of education; for better teaching job.

- Retirement. 


\section{RESULTS}

Below, I present the results of the three stages of the analysis: First, a summary of the data on the overall magnitude of teacher turnover and its role in teacher demand and school staffing problem; second, a regression analysis of the predictors of turnover; third, a detailed examination of the reasons teachers give for their departures.

\section{Levels of Turnover and School Staffing Problems}

Teaching is a relatively large occupation: it represents four percent of the entire civilian workforce. There are, for example, over twice as many K-12 teachers as registered nurses and five times as many teachers as either lawyers or professors (Statistical Abstract, 1998). Moreover, the rate of turnover appears to be higher than in many other occupations. One of the best known sources of national data on rates of employee turnover, the Bureau of National Affairs, has shown that nationwide levels of total departures have been quite stable over the past decade, averaging 11 percent per year (Bureau of National Affairs, 1998). ${ }^{11}$ While the data on nationwide employee turnover provide an overall benchmark, a more similar point of comparison is nursing, which, like teaching, is a predominantly female occupation that has experienced perennial workplace staffing problems. A recent survey found the mean turnover rate of registered hospital nurses in the mid 1990s was 12 percent (Mercer, 1999). ${ }^{12}$ Comparison of the TFS data with either nurses' or the employee turnover rate suggests that teaching has a relatively high turnover rate: 15 percent in 1988-89, 13.2 percent in 1991-92, and 14.3 percent in 1994-95.

Elsewhere I have reported in detail the SASS data on the levels and variations of school staffing problems: the difficulties schools have adequately staffing classrooms with qualified teachers (Ingersoll, 1999). I will briefly summarize these data in order to focus on the topic of particular interest here: the connection between teacher turnover and these school staffing problems.

Consistent with the shortage predictions discussed earlier, data from SASS and other NCES data sources show that demand for teachers has increased since the mid 1980s. Since 1984, student enrollments have increased, most schools have had job openings for teachers, and the size of the teaching workforce (K-12) has increased, although the rate of these increases began to decline slightly in the late 1990s (Gerald, 1998; Snyder et al., 1997). Most important, substantial numbers of those schools with teaching openings have experienced difficulties with recruitment. In both 1990-91 and 1993-94 about 47 percent of those with openings reported some degree of difficulty finding qualified candidates in one or more fields. But, even when the rates of enrollment increases were at their peak, in any given field, only a minority of the total population of schools actually experienced recruitment problems. For instance, the data show that in 1993-94, 35 percent of secondary schools had job openings for English teachers and about one quarter of these indicated they had at least some difficulty filling these openings-but this represented only nine percent of all secondary schools. Similarly, 34 percent of secondary schools had job openings for math teachers and just under half of these indicated they had at least some difficulty filling these math openings-but this represented only 16 percent of all secondary schools. Likewise, 27 percent of all schools had job openings for special education teachers and just over half of these indicated they had at least some difficulty filling these openings-but this represented only 15 percent of all schools. ${ }^{13}$

Moreover, for several reasons, the data suggest that these hiring difficulties were not primarily due to shortages in the conventional sense of an overall deficit in the pool of qualified candidates driven by enrollment and retirement increases. First, substantial numbers of schools have had staffing problems in fields such as English 
Table 2: Teacher Flows In and Out of Schools

\begin{tabular}{lccc} 
& $\begin{array}{c}\mathbf{1 9 8 7 - 8 8} \\
\text { School Year }\end{array}$ & $\begin{array}{c}\mathbf{1 9 9 0 - 9 1} \\
\text { School Year }\end{array}$ & $\begin{array}{c}\mathbf{1 9 9 3 - 9 4} \\
\text { School Year }\end{array}$ \\
\hline Total Hires - since prior year & 361,649 & 387,807 & 377,135 \\
$\quad$ New Entrants & 178,344 & 191,179 & 192,550 \\
$\quad$ Movers & 183,305 & 196,628 & 184,585 \\
Total Teaching Force - during year & $2,630,335$ & $2,915,774$ & $2,939,659$ \\
Total Turnover - during subsequent year & 390,731 & 382,879 & 417,588 \\
$\quad$ Movers & 218,086 & 208,885 & 204,680 \\
$\quad$ Leavers & 172,645 & 173,994 & 212,908 \\
$\quad$ Retirees & 35,179 & 47,178 & 50,242 \\
\hline
\end{tabular}

and social studies, fields that have long been known to have overall surpluses. Second, the data indicate that the hiring of new teachers is not primarily due to student enrollment increases, but to pre-retirement turnover.

Table 2 shows data from the three cycles of SASS indicating the total size of the teaching force and the magnitude of the major flows in and out of this force. The data show that teacher turnover is, numerically, a sizable phenomenon; for example, in 1994-95, from a force of just under three million, 417,588 teachers departed their teaching jobs. Moreover, these data show that departures have been equivalent to, or more than, the numbers of new hires. For instance, 191,179 teachers newly entered the occupation for the 1990-91 school year. However, in the following 12 months, 173,994 teachers-equivalent to 91 percent of those just hired-left the occupation altogether. In 1993-94, three years later, 192,550 teachers newly entered the occupation, but in the following 12 months, 212,908 — equivalent to 110 percent of those just hiredleft the occupation. ${ }^{14}$

Finally, although teacher retirements have increased in recent years, they account for only a small portion of total turnover. For example, in 1994-95 there were 50,242 retirees, accounting for only 24 percent of the 212,908 leavers and only 12 percent of the total turnover of 417,588 . Table 2 shows these patterns are consistent across all three cycles of the data. These data suggest an image of the teaching profession as a "revolving door," an occupation in which there are relatively large flows in, through, and out of schools in recent years, only partly accounted for by student enrollment increases or teacher retirements.

Not all of the flows out of schools result in a permanent loss of teachers. One form of this revolving door is represented by temporary attrition-teachers who leave teaching but return in later years (for insightful work on this, see Murnane et al., 1991). Another form is represented by migrants who move to teaching jobs in other schools. About half of the total teacher turnover is migration. In 1994-95, migration was 204,680 (or seven percent of turnover) and attrition was 212,908 (or 7.3 percent of turnover) (see Table 2). ${ }^{15}$ Unlike attrition, teacher migration is a form of turnover that does not decrease the overall supply of teachers because departures are simultaneously new hires. As a result, it would seem reasonable to conclude that teacher migration does not contribute to the problem of staffing schools. From a macro and systemic level of analysis, this is probably correct. However, from an organizationlevel perspective, the data suggest teacher migration does contribute to the problem of staffing schools. 
From the viewpoint of those managing at the school-level, teacher migration and attrition have the same effect: in either case it results in a decrease in staff, which usually must be replaced. A sufficient teacher supply pool would, of course, ease replacement; however, the data suggest that an overall lack of supply is neither the sole, nor dominant factor, behind staffing problems. The degree of staffing problems varies greatly among different types of schools even in the same jurisdiction; and schools ostensibly drawing from the same teacher supply pool can have significantly different staffing scenarios. Other research has found, for example, that in the same metropolitan area in the same year some schools have extensive waiting lists of qualified candidates for their teaching job openings, while other nearby schools have great difficulty filling their teaching job openings with qualified candidates (National Commission on Teaching, 1997). Consistent with this fact, analysis of variance of the SASS data reveals that the variation in hiring difficulties among schools is far greater within, than between, states. ${ }^{16}$ Understandably, schools with teacher recruitment problems are also more likely to have teacher retention problems. As mentioned above, the majority of schools do not experience difficulty filling their openings with qualified candidates. But, the data show schools that do report difficulties filling their openings are almost twice as likely to have above-average turnover rates as are schools reporting no difficulties. That is, the data show that school staffing difficulties are correlated with higher levels of turnover.

Moreover, the data show that school-to-school differences in turnover are significant. For example, as illustrated in Figure 2, high-poverty (poverty enrollment of 50 percent or more) public schools have higher turnover rates than do more affluent

\section{Figure 2: Percent of Employee Turnover and Percent of Teacher Turnover, by Selected School Characteristics}

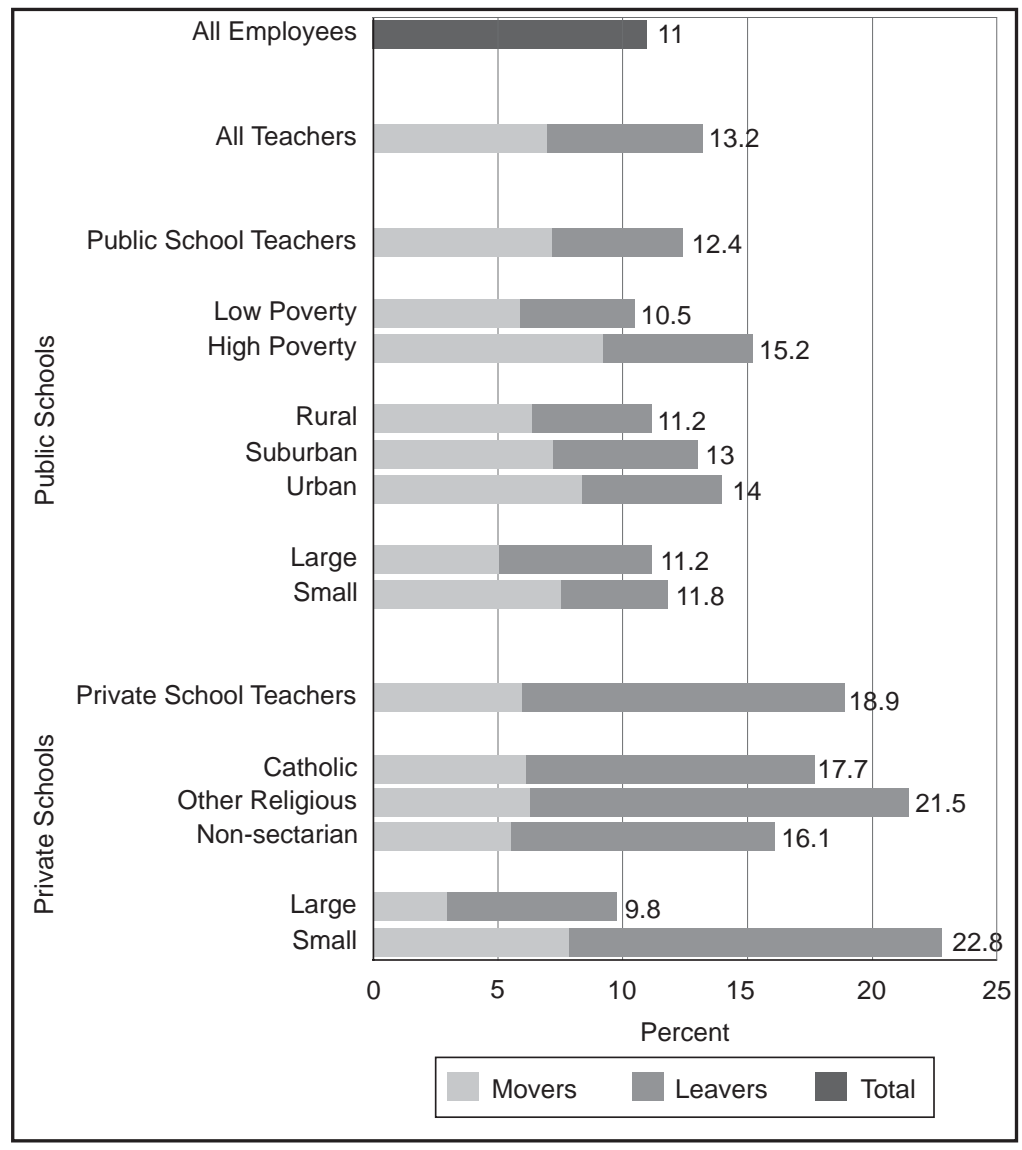


(poverty enrollment below 15 percent) public schools. Interestingly, urban public schools have only slightly more turnover than do suburban and rural public schools. More salient are the differences in rates of turnover according to the sector and size of the school. Private schools have higher turnover rates than public schools, and within the private sector, smaller schools have substantially higher rates of turnover than do larger schools. ${ }^{17}$

On one end of the scale lie larger (600 or more students) private schools with among the lowest average turnover rate-about 10 percent-close to what is found in other occupations. On the other end of the scale lie smaller (fewer than 300 students) private schools. It should be noted that larger private schools employ only a small portion of all private school teachers, while smaller private schools represent 81 percent of all private schools and employ 56 percent of all private school teachers in the United States. ${ }^{18}$ In rates of turnover, smaller private schools have the highest average levels: about 23 percent. The turnover rate in these schools is significantly higher, for instance, than the rate in high-poverty public schools and more than double the national average for other kinds of employees. The following section turns to an examination of the sources of high teacher turnover.

\section{Predictors of Turnover}

Table 3 presents three multiple regression models that examine which of the school-to-school differences in turnover rates, described above, remain salient after controlling for the characteristics of teachers and also whether school organizational conditions impact teacher turnover, after controlling for the characteristics of schools and teachers.

In the first model, the relationship between the teacher characteristics as a group (Model 1 of Table 3) and the likelihood of turnover is statistically significant. The age of teachers is the most salient predictor of the likelihood of their turnover. Both younger (under 30) and older (over 50) teachers are more likely to depart than are middleaged teachers. For instance, the relative odds of young teachers departing are 184 percent higher than for middle-aged teachers. The analysis also shows that special education teachers are more likely to depart than other teachers. The coefficient for math and science teachers is, however, negative, but this predictor changes when I control for school characteristics described in Model 2 below. Male teachers are less likely to depart than are female teachers and minority teachers are also less likely to depart than are white teachers.

When school characteristics are added to the model as a group (Model 2 of Table 3), the model likelihood statistic decreases by a statistically significant amount. School sector and school size, in particular, stand out as key variables. In private schools and in smaller schools, teachers depart at higher rates. For example, the odds of private school teachers departing are 17 percent higher than for public school teachers. An enrollment increase of 100 students is associated with a decrease in the odds of teachers departing by three percent. In addition, teachers in both rural and suburban schools are slightly less likely to turn over than are those in urban schools. Finally, teachers in secondary schools have slightly lower rates of turnover than do those in elementary and K-12 combined schools.

The question of particular interest here is: after controlling for the characteristics of teachers and schools, are the organizational conditions of schools associated with turnover? Model 3 of Table 3 adds the four measures of school organizational conditions to address this question. All are associated with turnover, after controlling for the characteristics of teachers and schools. Teachers in schools with higher salaries are less likely to depart. For example, an increase of $\$ 5,000$ in the normal salary provided to teachers with a masters degree and 20 years of experience is associated 
with a four percent decrease in the odds of a teacher departing. In schools that provide more support from administrators and with lower levels of student discipline problems, turnover rates are distinctly lower. For example, on a four unit scale, a one unit increase in reported student discipline problems in schools is associated with a 23 percent increase in the odds of a teacher departing. Finally, schools with higher levels of decision-making influence and autonomy have lower levels of turnover. For example, a one unit increase in reported teacher influence in schools (on a six unit scale) is associated with a 17.5 percent decrease in the odds of a teacher departing. As with Model 2, the introduction of these new variables reduces the model likelihood statistic by a statistically significant amount. Moreover, once organizational conditions are controlled, the coefficients for rural and suburban decreased, suggesting that lower rates of turnover in rural and suburban schools are partly mediated, or accounted for, by these conditions. On the other hand, once organizational conditions are controlled, the coefficients for private, size, and secondary-level all increased.

Table 3: Logistic Regression Analysis of the Likelihood of Teacher Turnover

\begin{tabular}{|c|c|c|c|c|c|c|}
\hline & \multicolumn{2}{|c|}{ Model 1} & \multicolumn{2}{|c|}{ Model 2} & \multicolumn{2}{|c|}{ Model 3} \\
\hline & (b) & (se) & (b) & (se) & (b) & (se) \\
\hline Intercept & $-2.1^{*}$ & .003 & $-1.89^{*}$ & .08 & $-.69^{\star}$ & .029 \\
\hline \multicolumn{7}{|l|}{ Teacher Characteristics } \\
\hline Young & $1.0^{*}$ & .01 & $.98^{*}$ & .005 & $1.01^{*}$ & .005 \\
\hline Old & $.88^{*}$ & .005 & $.85^{\star}$ & .005 & $.92^{*}$ & .006 \\
\hline Math/Science & .01 & .006 & $.12^{*}$ & .006 & -.004 & .007 \\
\hline Special Education & $.22^{*}$ & .006 & $.27^{*}$ & .006 & $.28^{*}$ & .006 \\
\hline Male & $-.15^{\star}$ & .004 & $-.10^{\star}$ & .005 & $-.07^{\star}$ & .005 \\
\hline Minority & -.01 & .005 & $-.08^{\star}$ & .006 & $-.12^{*}$ & .006 \\
\hline \multicolumn{7}{|l|}{ School Characteristics } \\
\hline Private & & & $.15^{\star}$ & .006 & $.21^{*}$ & .008 \\
\hline Size $(x 100)$ & & & $-.03^{*}$ & .0005 & $-.04^{*}$ & .001 \\
\hline Rural & & & $-.37^{*}$ & .005 & $.33^{*}$ & .005 \\
\hline Suburban & & & $-.12^{*}$ & .005 & $-.05^{\star}$ & .005 \\
\hline Secondary Level & & & $-.05^{\star}$ & .005 & $-.10^{*}$ & .005 \\
\hline \multicolumn{7}{|l|}{ Organizational Conditions } \\
\hline Advanced Salary $(x 1,000)$ & & & & & $-.01^{*}$ & .003 \\
\hline Administrative Support & & & & & $-.10^{*}$ & .005 \\
\hline Student Conflict & & & & & $.21^{*}$ & .006 \\
\hline Faculty Influence & & & & & $.19^{*}$ & .004 \\
\hline -2 Log Likelihood & $1,899,938$ & & $1,885,945$ & & $1,877,000$ & \\
\hline $\mathrm{N}$ & & 5643 & & 5643 & & 5643 \\
\hline
\end{tabular}


Table 4 presents separate models of turnover for public and private schools. It examines in more detail what accounts for differences in turnover within each school sector and to what extent the association of these variables with turnover differs across sectors. ${ }^{19}$

Among public schools, teachers in high-poverty schools have higher rates of turnover than do those in more affluent public schools, but this relationship is not strong. ${ }^{20}$ Interestingly, teachers in suburban public schools are slightly more likely to turn over than those in urban public schools, once other factors are controlled. School size and school district size are both inversely related to turnover in public schools.

The affiliation or orientation of private schools is associated with turnover. NonCatholic religious private schools have more turnover than do non-sectarian private schools; the coefficient for Catholic schools is also positive but does not achieve

\section{Table 4: Logistic Regression Analysis of the Likelihood of Teacher Turnover}

\begin{tabular}{|c|c|c|c|c|}
\hline & \multicolumn{2}{|c|}{ Public Schools } & \multicolumn{2}{|c|}{ Private Schools } \\
\hline & (b) & $(\mathrm{se})$ & (b) & (se) \\
\hline Intercept & $-1.02^{*}$ & .032 & $2.02^{*}$ & .08 \\
\hline \multicolumn{5}{|l|}{ Teacher Characteristics } \\
\hline Young & $1.05^{\star}$ & .006 & $.67^{\star}$ & .014 \\
\hline Old & $1.00^{*}$ & .006 & $.13^{*}$ & .02 \\
\hline Math/Science & $.03^{*}$ & .007 & $-.03^{*}$ & .02 \\
\hline Special Education & $.29^{*}$ & .006 & $.74^{\star}$ & .04 \\
\hline Male & $-.05^{\star}$ & .005 & $.07^{\star}$ & .01 \\
\hline Minority & $-.19^{*}$ & .006 & $.33^{*}$ & .02 \\
\hline \multicolumn{5}{|l|}{ School Characteristics } \\
\hline Size $(x 100)$ & $-.03^{*}$ & .001 & $-.19^{*}$ & .003 \\
\hline Rural & $-.27^{*}$ & .006 & $-.19^{\star}$ & .015 \\
\hline Suburban & $.06^{*}$ & .006 & $-.44^{*}$ & .013 \\
\hline Secondary Level & $-.07^{*}$ & .01 & $.43^{*}$ & .020 \\
\hline Public District Size (x 10,000) & $-.001^{*}$ & .0002 & - & - \\
\hline Poverty Enrollment & $.004^{*}$ & .0001 & - & - \\
\hline Catholic Private & - & - & .02 & .02 \\
\hline Other Religious Private & - & - & $.17^{\star}$ & .02 \\
\hline \multicolumn{5}{|l|}{ Organizational Conditions } \\
\hline Advanced Salary $(x 1,000)$ & $-.01^{*}$ & .0003 & $-.02^{*}$ & .001 \\
\hline Administrative Support & $-.14^{*}$ & .006 & $-.07^{*}$ & .013 \\
\hline Student Conflict & $.11^{*}$ & .007 & $.09^{*}$ & .02 \\
\hline Faculty Influence & $-.15^{*}$ & .005 & $-.54^{*}$ & .011 \\
\hline -2 Log Likelihood & $1,636,878$ & & 213,823 & \\
\hline $\mathrm{N}$ & & 4219 & & 1404 \\
\hline
\end{tabular}


significance. Moreover, the effects of several of the predictors differ between sectors. In public schools, math and science teachers are more likely to turn over than other teachers, but the effect is insignificant in private schools. In private schools, male teachers and minority teachers are both more likely to depart; in public schools the opposite is true. Teachers in private secondary schools are slightly more likely to turn over than those in either elementary or combined schools; whereas in the public sector, teachers in secondary schools are less likely to turn over than those in other schools. Notably for the focus of this analysis, in both sectors the effects of all four organizational conditions are significant and impact turnover in expected ways.

I also estimated the same overall model for movers and leavers separately (not shown here) to explore differences in the predictors of each. The data indicate that there are only a few differences. For instance, private school teachers are more likely to leave teaching altogether, but less likely to move to other schools, than are public school teachers. Notably, although both special education and math/science teachers are more likely to migrate than other kinds of teachers, neither group is more likely to leave teaching altogether than other teachers, once other factors are controlled. But overall, the models indicate that the kinds of teachers who are more likely to move from their teaching jobs are also more likely to leave their jobs. Likewise, school and organizational conditions associated with higher rates of teacher migration are similarly associated with higher rates of teacher attrition.

Finally, I estimated the same overall model for voluntary departures only (not shown here). This subset of turnover excluded those departing because of retirement, layoffs, terminations, or school closings. When looking at departures that are, ostensibly, a matter of choice, one would expect organizational conditions to have more influence. The data show that this is the case; while many of the other factors change little, the effects of the four organizational measures all increase.

\section{Reasons for Turnover}

The analysis thus far has established the magnitude of teacher turnover and indicated its association with organizational conditions, after controlling for the characteristics of schools and teachers. The next stage of this analysis presents a more in-depth look at the reasons teachers themselves give for their turnover and their variation among different types of schools. However, rather than present data on a wide range of school comparisons, this section focuses on two particular types of schools: urban, high-poverty public schools and small private schools. These two types of schools are often juxtaposed as extreme opposites (e.g., Bryk et al., 1990), and the results of the preceding analysis show that their rates of turnover also diverge. This section more closely examines the reasons for both migration and attrition and for both voluntary and involuntary departures in these schools.

The top portion of Table 5 presents data on the rates of and self-reported reasons for both teacher migration and attrition for all schools, for high-poverty, urban public schools, and for small private schools. In addition, for all teachers who departed because of job dissatisfaction, the bottom portion of the table presents data on the self-reported reasons for their dissatisfaction. ${ }^{21}$ Utilizing these self-report data in conjunction with the prior regression analyses (based on data from a different set of respondents) provides a means of comparison and, hence, checking the two sets of findings concerning the effect of school characteristics and organizational conditions on turnover.

The overall teacher turnover rate is 13.2 percent. The rate of turnover in urban, high-poverty public schools is slightly above average (14.4 percent) and the rate in small private schools is significantly higher (22.8 percent). This rate gap between 


\section{Table 5: Percent of Teacher Turnover and Percent of Teachers Reporting Various Reasons for their Turnover, by School Type}

\begin{tabular}{|c|c|c|c|c|c|c|}
\hline \multirow[b]{3}{*}{ Rates of Turnover } & \multicolumn{2}{|c|}{ All Schools } & \multicolumn{2}{|c|}{$\begin{array}{l}\text { Urban, High-poverty } \\
\text { Public Schools }\end{array}$} & \multicolumn{2}{|c|}{$\begin{array}{c}\text { Small } \\
\text { Private Schools }\end{array}$} \\
\hline & Movers & Leavers & Movers & Leavers & Movers & Leavers \\
\hline & 7.2 & 6 & 8.7 & 5.7 & 7.8 & 15 \\
\hline \multicolumn{7}{|l|}{ Reasons for Turnover } \\
\hline Retirement & - & 27 & - & 32 & - & 8 \\
\hline School Staffing Action & 41 & 12 & 34 & 5 & 22 & 13 \\
\hline Personal & 33 & 45 & 40 & 41 & 42 & 51 \\
\hline To Pursue Other Job & 25 & 24 & 28 & 28 & 27 & 31 \\
\hline Dissatisfaction & 27 & 25 & 29 & 19 & 56 & 23 \\
\hline \multicolumn{7}{|l|}{ Reasons for Dissatisfaction } \\
\hline Inadequate Administrative Support & 38 & 30 & 25 & 18 & 25 & 34 \\
\hline Poor Salary & 47 & 45 & 24 & 46 & 79 & 73 \\
\hline Student Discipline Problems & 18 & 30 & 29 & 27 & 3 & 12 \\
\hline Lack of Faculty Influence & 13 & 18 & 26 & 11 & 12 & 9 \\
\hline Lack of Student Motivation & 10 & 38 & 27 & 50 & 3 & 14 \\
\hline Class Sizes Too Large & 6 & 13 & 8 & 7 & .5 & 13 \\
\hline Inadequate Time to Prepare & 10 & 23 & 8 & 8 & 4 & 18 \\
\hline Unsafe Environment & 11 & 2 & 10 & 26 & 1 & 0 \\
\hline \multicolumn{7}{|l|}{ Poor Opportunity for Professional } \\
\hline Advancement & 9 & 10 & 5 & 24 & 15 & 9 \\
\hline Lack of Community Support & 12 & 5 & 11 & 0 & 2 & 1 \\
\hline Interference in Teaching & 5 & 5 & 12 & 1 & 8 & 4 \\
\hline $\begin{array}{l}\text { Lack of Professional Competence } \\
\text { of Colleagues }\end{array}$ & 8 & 4 & 23 & 10 & 5 & 4 \\
\hline Intrusions on Teaching Time & 5 & 11 & 7 & 7 & 2 & 1 \\
\hline
\end{tabular}

urban, high-poverty public and small private schools is almost entirely due to differing levels of attrition, rather than migration. The migration rate for teachers in urban, high-poverty public schools, like that for all teachers, is only slightly different from that of teachers in small private schools (8.7 percent compared to 7.8 percent). Notably, however, teachers in small private schools leave the teaching occupation at a rate over double that of teachers in urban, high-poverty public schools (15 percent compared to 5.7 percent).

Among the least prominent reasons for turnover is retirement. The latter actually accounts for less than a third of those leaving the occupation (27 percent) and only a small part (12 percent) of total turnover (movers and leavers). Retirement also does 
not account for the relatively high rates of attrition in small private schools. Indeed, urban, high-poverty public schools have far higher levels of retirement turnover than do small private schools (32 percent compared to eight percent).

School staffing cutbacks due to lay-offs, school closings, and reorganizations account for a larger proportion of turnover (41 percent of migration and 12 percent of attrition) than does retirement. Moreover, this kind of turnover provides some explanation for the high rates of attrition in small private schools. More than twice as much attrition in private schools is reported due to staffing actions as is reported in urban, high-poverty public schools. Some of this difference may be a result of private school administrators laying off low-performing staff: a capability held to be less available to public school administrators (Chubb \& Moe, 1990). However, the data also show that, overall, staffing actions account for only a small portion of attrition in either type of school (five percent and 13 percent). Staffing actions more often result in migration to other teaching jobs rather than departure from the teaching occupation altogether, and these cross-school movements are more common in urban, highpoverty public schools than in small private schools (34 percent compared to 22 percent). The former's higher rates of school staffing migration are most likely a result of within-school district transfers, a type of flow rarely found in private school systems.

Personal reasons, such as departures for pregnancy, child rearing, health problems, and family moves, are more often reported as reasons for more turnover than either retirement or staffing actions (33 percent of migration and 45 percent of attrition). Moreover, this kind of turnover also provides some explanation for the high rates of attrition in small private schools. Teachers in small private schools are slightly more likely to depart for personal reasons than are those in urban, high-poverty public schools (51 percent compared to 41 percent), but the data also show these motives are common to all schools.

Finally, two reasons directly related to the organizational conditions of teaching are, together, the most prominent source of turnover. Forty-two percent of all departing teachers report as a reason either job dissatisfaction or the desire to pursue a better job, another career, or to improve career opportunities in or out of education. Teachers who migrate to other schools list low salaries, lack of support from the school administration, student discipline problems, and lack of teacher influence over decision making as the primary reasons underlying their move. Likewise, dissatisfaction underlying attrition is most often reported as due to low salaries, lack of support from the school administration, lack of student motivation, and student discipline problems. These findings from the self-report data are highly consistent with the results in the prior regression analysis, lending confidence to both stages of the analysis.

Similar proportions of teachers in urban, high-poverty public schools and small private schools report departing in order to pursue a better job or other career opportunities. But surprisingly, far more turnover in small private schools is linked to job dissatisfaction than in urban, high-poverty public schools. Why is this so?

For teachers in urban, high-poverty public schools, the reasons given for the dissatisfaction underlying their turnover are not surprising. Of those who depart because of job dissatisfaction, a quarter or more report each of the following five reasons: low salaries, a lack of support from the administration, student discipline problems, lack of student motivation, and lack of influence over decision-making. However, several factors stand out as not serious enough to lead to much turnover in these schools: large class sizes, intrusions on classroom time, lack of planning time, lack of community support, and interference with teaching. 
In contrast, although a larger portion of those departing small private schools indicated they do so because of job dissatisfaction, the major reasons for their dissatisfaction are fewer in number. Most prominent is salary. About three quarters of those departing small private schools because of job dissatisfaction report poor salaries as a reason. In addition, about one third of the dissatisfied indicate that a lack of support from the school's administration led to their departure.

In sum, the data indicate that teachers depart their jobs for a variety of reasons. As expected, there are differences between movers and leavers and differences between small private and urban poor public schools. But what is noteworthy is the amount of similarity in the results across different types of schools, across different types of turnover, and across different types of data. Retirement accounts for the least number of departures; staffing actions account for slightly more. A large proportion of teachers indicate they departed for personal reasons, and the largest proportion of departures had to do with job dissatisfaction and desire to seek better jobs or career opportunities.

\section{DISCUSSION AND IMPLICATIONS}

The objective of this study is two-fold: to first establish the role of teacher turnover in the staffing problems of schools and then to closely examine the role of school characteristics and organizational conditions in teacher turnover. As reviewed earlier, there are two educational issues, important in both the realms of research and policy, for which this study has implications: teacher shortages and school community and effectiveness. Below, I discuss these implications.

\section{Teacher Turnover and Teacher Shortages}

Since the early 1980s, educational theory has predicted that shortfalls of teachers resulting primarily from two converging demographic trends-increasing student enrollments and increasing teacher retirements-will lead to problems staffing schools with qualified teachers and, in turn, lower educational performance (e.g., National Commission on Excellence in Education, 1983; National Commission on Teaching, 1997). Concern over shortages has given impetus to empirical analysis, much of it focused on teacher turnover (e.g., Grissmer \& Kirby, 1987, 1992, 1997; Heyns, 1988; Murnane, 1981, 1987; Murnane, Singer, \& Willett, 1988).

This analysis attempts to build on these bodies of theory and research by adding a previously under-emphasized perspective. My theoretical perspective, drawn from the sociology of organizations, occupations, and work, is that teacher turnover and, in turn, school staffing problems cannot be understood fully without examining the organizational characteristics and conditions of the schools in which turnover and staffing problems are embedded and also examining turnover at the level of the organization.

The data show that teacher turnover is a significant phenomenon and a dominant factor driving demand for new teachers and, in turn, creating school staffing problems. While it is true that student enrollments are increasing, the demand for new teachers is primarily due to teachers moving from or leaving their jobs at relatively high rates. Consistent with prior empirical research (e.g., Bobbitt et al., 1994; Hafner \& Owings, 1991; Grissmer \& Kirby, 1987, 1992, 1997; Murnane, Singer, \& Willett, 1988), the analysis indicates that teacher characteristics such as specialty field and age account for a significant amount of turnover. Teacher retirements, in particular, stand out. But, net of teacher effects, there are also significant effects of school and organizational characteristics on turnover that have largely been overlooked by previous theory and research. While it is true that teacher retirements are increasing, the overall amount 
of turnover accounted for by retirement is relatively minor when compared to that resulting from other causes, such as teacher job dissatisfaction and teachers seeking better jobs or other careers.

These findings suggest that school staffing problems are neither synonymous with, nor primarily due to, teacher shortages in the conventional sense of a lack or deficit of qualified candidates. Moreover, this analysis suggests that increases in student enrollment and increases in teacher retirement are not the primary factors at the root of staffing difficulties, as current theory holds. Rather, the data suggest that school staffing problems are primarily due to excess demand resulting from a "revolving door" where large numbers of teachers depart their jobs for reasons other than retirement. The findings of this analysis have important implications for educational policy. Supply and demand theory holds that where the quantity of teachers demanded is greater than the quantity of teachers supplied, there are two basic policy remedies: increase the quantity supplied or decrease the quantity demanded. As noted in the beginning of this article, teacher recruitment, an example of the former approach, has been and continues to be the dominant approach in addressing school staffing inadequacies (Clinton, 1999; Feistritzer, 1997; Kopp, 1992). To be sure, some schools in some jurisdictions suffer from inadequate numbers in the quantity of qualified teachers supplied. A case in point is California where increased hiring due to initiatives to reduce elementary school class sizes has created a temporary imbalance between supply and demand. However, this analysis suggests that recruitment programs alone will not solve these or other school staffing problems if they do not also address the problem of teacher retention. The data show that the solution to staffing problems does not primarily lie in increasing an insufficient supply, but rather in decreasing excess demand. In short, this analysis suggests that recruiting more teachers will not solve staffing inadequacies if large numbers of such teachers then leave.

Current policies will not only not solve school staffing problems, but they will also divert attention from the primary underlying problem-the manner in which schools are managed and teachers are treated. From the perspective of this analysis, schools are not simply victims of large-scale, inexorable demographic trends; there is a significant role for the management of schools in both the genesis and solution of school staffing problems. Rather then increase the quantity of teacher supply, an alternative solution to school staffing problems is to decrease the demand for new teachers by decreasing turnover. The data suggest that improvements in organizational conditions, such as increased salaries, increased support from the school administration, reduction of student discipline problems, and enhanced faculty input into school decision-making, would all contribute to lower rates of turnover, thus diminish school staffing problems, and ultimately aid the performance of schools.

\section{Teacher Turnover, School Community, and School Effectiveness}

The results of this analysis also have implications for a second area of education theory and policy: school community and effectiveness. Educational sociologists, in particular, have long held that the presence of a sense of community and cohesion among families, teachers, and students is important for the success of schools (e.g., Durkheim, 1925/1961; Waller, 1932; Parsons, 1959; Coleman \& Hoffer, 1987; Grant, 1988; Rosenholtz, 1989). In general, large public schools, especially those in urban, high-poverty areas, are often cited as less likely to exhibit a sense of community (e.g., Bryk et al., 1990). In contrast, many have argued that small schools are more likely to have a communal climate, providing support for a "small is beautiful" viewpoint perennially popular among educational reformers (for reviews of the debate on school size, see Bryk et al., 1990; Guthrie, 1979; Walberg \& Walberg, 1994). Moreover, some 
researchers have tied the effectiveness of private schools, especially the religiously oriented, to a coherent and unified mission and sense of community (e.g., Bryk, Lee, \& Holland, 1993; Coleman \& Hoffer, 1987).

Underlying my analysis is the premise, drawn from the sociology of organizations, occupations, and work, that high levels of employee turnover are tied to how well organizations function. From this perspective high rates of teacher turnover are of concern not only because they may be an indication of underlying problems in how well schools function, but also because they can be disruptive, in and of themselves, for the quality of school community and performance. This analysis, however, does not explicitly examine the relationship between teacher turnover, school community, and school effectiveness. But, if one accepts the above premise, then the results here raise serious questions for the educational literature on school community, concerning, especially, which kinds of schools are more likely to have a positive sense of community and what effect teacher attachment to schools has on school community and performance.

The data show that neither larger schools, nor public schools in large school districts, nor urban public schools, nor high-poverty public schools have the highest rates of teacher turnover. In contrast, small private schools stand out for their relatively high rates of turnover. Moreover, among private schools there are large variations in turnover. In contrast to the relatively low turnover rates in large private schools, small private schools lose, on average, almost one quarter of their faculty each year, most of whom are full-time employees. In such cases, ostensibly, an entire staff could change within a school in only a short number of years. Clearly, small private school turnover disproportionately contributes to system-wide teacher supply and demand imbalances. But, in addition, high levels of teacher turnover in small private schools are of both theoretical and policy concern because these are the very schools that presumably are most likely to have a performance-enhancing, tight-knit community. Interestingly, in previous research I have found that private school teachers are far more likely to switch to public school jobs than public school teachers are to switch to private school jobs. Indeed, almost half of those who migrate from private school teaching jobs to other teaching jobs move to public schools (Ingersoll, 1995a). These findings stand out because teachers in private schools consistently report higher levels of job satisfaction and more positive school climates than do teachers in other kinds of schools (e.g., Ingersoll, 1997; Reyes, 1991).

What accounts for these findings? One reason for high rates of turnover in small private schools is teacher compensation. Salaries in small private schools are relatively low. For example, the SASS data indicate that in 1993-94, the average starting salary for a teacher with a bachelor's degree and no experience in a small private school was about $\$ 16,000$, and the average maximum salary (the highest offered by the school to any teacher) was about $\$ 28,000$. In contrast, in the same year, the average starting salary for a teacher with a bachelor's degree and no experience in public schools was about $\$ 22,000$, and the average maximum salary was about $\$ 40,500$. These figures suggest that, despite high levels of job satisfaction, some teachers in small private schools depart because they cannot afford to remain.

The data in Table 5 also indicate, however, that low salaries are not the only reason for the high level of turnover in small private schools. Significant numbers of those who depart their jobs in these schools report they are dissatisfied with the administration of their school. What explains these surprisingly high levels of dissension between teachers and administrators in small private schools?

Below I offer an explanation as a hypothesis for future empirical investigation. This hypothesis is drawn from my research on the organizational and occupational conditions in schools and also from my own experiences as a former secondary-school 
teacher in both public and private schools. ${ }^{22}$ High levels of teacher turnover in small private schools may, paradoxically, be caused by a coherent mission, clearly defined values, and a tight-knit sense of community.

Numerous analysts have pointed out the negative consequences of the impersonal, alienated, "shopping mall" organizational climate often found in large public schools (e.g., Bryk, et al., 1990). Another characteristic often found in this kind of organization, however, is diversity. Organizations without a coherent mission, clearly defined values, or a tight-knit sense of community may, intentionally or unintentionally, allow more choice and be more tolerant of differences. From the viewpoint of teachers, larger public schools lacking such coherence and community may provide more academic freedom and more career options. To use Hirschman's classic (1970) framework, members who disagree with the policies of an organization face three basic options: exit, voice, or loyalty. For teachers who disagree with school policies, large public schools may be more likely to provide options, other than either conformity to existing policies or an exit from the job. Moreover, simply by virtue of their size, large schools and large school systems may also offer more job and mobility opportunities for teachers either within the school or within the district.

In contrast, a coherent mission, clearly defined values, and a tight-knit sense of community may be a source of strength and success in small and religious private schools, as argued by Coleman and Hoffer (1987), but may also be a source of conflict. Emphasizing one set of goals, values, policies, and programs, by definition, results in de-emphasizing others. From the viewpoint of teachers, key questions are these: Whose policies are emphasized by the school? What options and choices are available for those who disagree with the dominant policies, values, and goals? My hypothesis, reflecting the organizational perspective of this analysis, is that teachers' choices to stay or exit are shaped by particular occupational and organizational conditions in schools. For instance, if the school provides mechanisms for the protection of academic freedom and job security, such as tenure, and mechanisms for voicing opposition, such as teacher unions, those who disagree with school policies will be less likely to exit. However, if there are few mechanisms for the collective or individual expression of disagreement with school policies and few protections for those employees who challenge school policies, those who disagree with school policy will be more likely to exit. My hypothesis is that small and religious private schools are less likely to have teacher unions, tenure provisions, formal mechanisms for collective opposition to school policies, or faculty grievance procedures and, as a result, have higher rates of teacher turnover.

Finally, this study also raises another fundamental question: What impact do high rates of teacher turnover have on schools? My analysis has focused on the effects of school and organizational characteristics on teacher turnover, but the reverse is also an important issue and focus in organizational research (e.g., Price, 1989). This is especially pertinent for the case of private schools: What effects does turnover have on the community and performance of these kinds of schools? Of course, the departure of individuals who do not share the goals and values of the organization can be useful to maintain a coherent mission and sense of purpose. After reaching a certain threshold level, however, turnover may become a source of group disintegration, rather than group integration. At such a point, the negative consequences of turnover for organization stability and coherence would begin to overshadow the positive consequences for the organization resulting from the elimination of dissension. It is unclear, of course, where this threshold point is for schools, regardless of size and type. The organizational literature suggests that turnover rates of, for example, almost 25 percent will likely have a negative impact on organizational performance, especially if these are organizations, such as schools, for which coherence and continuity are deemed important for effectiveness (e.g., Mobley, 1982). To my knowledge there have 
been no studies that use national data to examine the impact of teacher turnover on school community and school performance. Such research could address vital questions: How well are schools able to cope with a recurring loss of staff and a recurring need to rehire? What does continual turnover mean for the ability of the teaching staff to establish teamwork and continuity of curricula and programs? How does the loss of teachers affect ties to parents, students, and the community? 


\section{ENDNOTES}

1 An important exception to this general trend is the recent work of Boe et al. (1998), which presents an unusually thorough look at the effects of a range of factors on teacher turnover.

2 Indeed, some of this research makes no connection between turnover and the larger theory or issues of shortages and staffing problems. It treats the study of teacher turnover as an isolated empirical topic, important for its own sake (e.g. Chapman \& Green, 1986; Chapman \& Hutcheson, 1982; Hafner \& Owings, 1991; Marso \& Pigge, 1991).

3 Steers and Momday calculated that, by 1981, well over 1,000 studies of employee turnover had been done.

4 Related articles from this larger project focus upon: overall levels of teacher supply, teacher turnover, and teacher qualifications (Ingersoll, 1995a); levels and causes of underqualified teachers (Ingersoll, 1999); turnover among math / science teachers (Ingersoll, 2000a); teacher quality and educational inequality (Ingersoll, 2000b); and the role of turnover in problems of educational inequality (Ingersoll, 2000c).

5 For details on the TFS, see Bobbitt et al., 1994.

6 It should be noted that the distinction between voluntary and involuntary is difficult to empirically capture (For discussion, see, e.g. Kalleberg \& Mastekaasa, 1998; Price, 1997). For example, while most assume retirements are involuntary, some categorize them as voluntary. Moreover, respondents may not accurately report whether they were laid off, fired, or retired. Here, as mentioned, I examine these types both together and separately and do not solely rely on self-report data.

7 See Price, 1997, pp. 532-7, for a discussion of different subsets and definitions of turnover.

8 The 1990-91 SASS did not collect data on poverty levels in private schools.

9 This is an important distinction, and it should also be noted that the measure of teacher salary utilized in this analysis is unusual. Teacher salary levels are often standardized according to a uniform salary schedule, based on the education levels and years of experience of the teachers. Especially with an aging teaching workforce, it can be unclear if differences in average salary levels are due to real differences in the compensation offered to comparable teachers at different schools or are due to differences in the experience and education levels of the teachers employed. That is, a school with older teachers may appear to offer better salaries, when, in fact, they do not. A more effective method of comparison across schools is to compare the normal salaries paid by schools to teachers at common points in their careers. This analysis examines data on the normal base year teacher salary for those with 20 years of experience and a master's degree. This measure represents the organizational financial rewards teachers can look forward to at an advanced point in their careers if they stay in their particular schools and, hence, could affect their decisions to depart or stay.

This measure also may have limitations. Some economists, for instance, might argue that school salary schedules do not accurately capture the effect of salary on rates of teacher turnover because candidates can obtain this information in deciding whether to accept a particular teaching job. From this viewpoint, since public school teachers are compensated according to published salary schedules 
that change infrequently, new entrants can predict with almost complete certainty how much they will be paid in each year in the future. Hence, if a teacher did accept a job, it suggests that he/she is satisfied with the school's salary levels and, hence, most likely would not be a factor in future turnover (Murnane, personal communication).

On the other hand, sometimes teachers may, of course, accept jobs with salaries below what they would prefer and then move in a few years when a better paying job opens up. Moreover, Goodlad (1984) and others have argued that, while money is not a major factor in teachers' choice of a job, it is a major factor in their decision to migrate or leave teaching. In this view, teachers begin their careers with less pecuniary and more altruistic motivations, but if these kinds of expectations are frustrated, salaries can become a source of considerable dissatisfaction. This analysis does not presume the validity of either view but simply tests whether differences in advanced salaries among schools are related to turnover.

10 This limitation applies to HLM, MLn, BUGS, VARCL, SAS' PROC MIXED/ GLMMIX, MIXREG, BMDP, Mplus, Stata and SABRE.

11 The Bureau of National Affairs, a leading research and information service for both business and non-business organizations, has gathered data on employee turnover for over two decades through quarterly surveys of human resource and employee relations executives. Its 1997 fourth quarter survey, for example, included 230 respondents representing about 300,000 employees from a wide range of organizations. The latter vary in size from those employing less than a hundred to those employing thousands and include both manufacturing, nonmanufacturing, finance and health care establishments. Turnover is defined as those who depart the organization and includes both migration to other organizations and those leaving the occupation altogether. Perhaps the best, albeit now dated, source of comparative data on occupational turnover rates is Chapter 4 of Price's seminal 1977 study on employee turnover.

12 William M. Merer, a leading human resource consulting firm, conducts research on hospital and nurse staffing issues in conjunction with the American Nurses Association and the American Organization of Nurse Executives, a division of the American Hospital Association. The data reported here are from the Survey of Registered Nurse Attraction and Retention conducted by Mercer in August 1999. The sample included human resource executives in 185 healthcare organizations. Of these, 93 percent were hospitals, two percent were long-term care providers, two percent were ambulatory organizations, and three percent home health providers. The median gross revenue of these organizations was $\$ 193$ million, and the median number of full time employees was 1800.

13 The data on school hiring difficulties from the 1993-94 SASS school questionnaire asked school officials how difficult or easy it was to fill the vacancies for this school year in each of 14 fields. I counted as having difficulty filling teaching vacancies all those schools reporting either: somewhat difficult, very difficult, or could not fill. The results were very similar to those obtained from similar items in both the 1987-88 and 1990-91 SASS data. The extent to which a school has hiring difficulties is perhaps one of the best indicators of staffing problems. However, it is, of course, not the only indicator of these problems. Elsewhere I examine in detail another indicator of school staffing problems, the extent of under-qualified teachers in classrooms. See Ingersoll, 1999. 
14 In keeping with my organizational-level perspective, the data in Table 2 are calculated at the level of the school. Hence "hires" and "departures" refer to those newly entering or departing a particular school. "New entrants" refers to those who did not teach the prior year, but some new entrants did teach in the past. Reassignments within a school are not defined as hires or departures.

15 Elsewhere I analyze in more detail the dynamic nature of teacher turnover and examine more closely the data showing the number, type, and magnitude of the flows of teachers into, through, and out of schools. See Ingersoll, 1995a.

16 Using a one-way random effects ANOVA model, the data show that the variance component within states was 44 times the size of the variance component between states. Intraclass correlation $=.022$.

17 In Figure 2, large schools are defined as those with 600 or more students; small schools are those with fewer than 300 students. High-poverty refers to schools with a poverty enrollment of 50 percent or more; low-poverty refers to schools with a poverty enrollment below 15 percent. Middle categories of size and poverty are omitted in the figure. Note that size and poverty are categorized here for purposes of illustration; they are treated as continuous variables in the forthcoming regressions.

18 These school population proportions are estimates derived from SASS.

19 Note that because some of the types of predictors used in the public and private models differ, Table 4 does not, of course, represent an exact comparison of sectoral differences of the predictors' effects.

20 Besides public schools in low-income and high-poverty communities, many have also argued that predominantly minority public schools also have very high levels of teacher turnover (e.g, Rosenholtz, 1985; Kozol, 1991). Because a school's poverty enrollment is very highly inter-correlated with its minority enrollment, I tested the effect of the latter factor on turnover in a separate model, not shown here. Like percent of poverty enrollment, the relationship between percent of minority enrollment and turnover was statistically significant, but not strong.

21 Note that the column segments in table 5 displaying percent reporting various reasons for turnover each add up to more than 100 percent because respondents could indicate up to three reasons for their departures. The same applies to the columns displaying reasons for dissatisfaction.

22 For detailed reports of my research on school differences in organization and occupational conditions, see Ingersoll, 1993, 1994, 1996. 
Bacharach, S., \& Bamberger, P. (1990). Exit and voice: Turnover and militancy intentions in elementary and secondary schools. Educational Administration Quarterly, 26, 316-344.

Barro, S. (1992). Models for projections of teacher supply, demand and quality. In E. Boe \& D. Gilford (Eds.), Teacher supply, demand and quality (pp. 129-209). Washington, DC: National Academy Press.

Bidwell, C. (1965). The school as a formal organization. In J. March (Ed.), Handbook of Organizations (pp. 973-1002). Chicago, IL: Rand McNally.

Bidwell, C., \& Karsarda, J. (1980). Conceptualizing and measuring the effects of school and schooling. American Journal of Education, 89, 401-431.

Bidwell, C., \& Quiroz, P. (1991). Organizational control in the high school workplace: A theoretical argument. Journal of Research on Adolescence, 1, 211-229.

Bluedorn, A. C. (1982). A unified model of turnover from organizations. Human Relations, 35, 135-153.

Bobbitt, S., Leich, M., Whitener, S., \& Lynch, H. (1994). Characteristics of stayers, movers, and leavers: Results from the teacher follow up survey, 1991-92. Washington, DC: National Center for Education Statistics.

Boe, E., \& Gilford, D. (1992). Teacher supply, demand and quality. Washington, DC: National Academy Press.

Boe, E., Bobbitt, S., \& Cook, L. (1997). Whither didst thou go? Journal of Special Education, 30, 371-389.

Boe, E., Bobbitt, S., Cook, L., Barkanic, G., \& Maislin, G. (1998). Teacher turnover in eight cognate areas: National trends and predictors. Philadelphia, PA: University of Pennsylvania, Center for Research and Evaluation in Social Policy.

Bryk, A., Lee, V., \& Smith, J. (1990). High school organization and its effects on teachers and students: An interpretive summary of the research. In W. H. Clune \& J. F. Witte (Eds.), Choice and control in American education, Volume 1: The theory of choice and control in education. New York: Falmer Press.

Bryk, A., Lee, V., \& Holland, P. (1993). Catholic schools and the common good. Cambridge, MA: Harvard University Press.

Bureau of National Affairs. (1998). BNAs quarterly report on job absence and turnover. Bulletin to Management. Washington DC: Bureau of National Affairs.

Burns, T., \& Stalker, G. M. (1961). The management of innovation. London: Tavistock.

Chapman, D., \& Hutcheson, S. (1982). Attrition from teaching careers: A discriminant analysis. The American Education Research Journal, 19, 93-105.

Chapman, D., \& Green, M. (1986). Teacher retention: A further examination. The Journal of Educational Research, 79, 273-279.

Chubb, J. E., \& Moe, T. (1990). Politics, markets and America's schools. Washington, DC: Brookings Institute.

Clinton, W. (1999). State of the Union Address. Washington DC: U.S. Government Printing Office. 
Coleman, J., \& Hoffer, T. (1987). Public and private schools: The impact of communities. New York: Basic.

Darling-Hammond, L. (1984). Beyond the commission reports: The coming crisis in teaching. Santa Monica, CA: Rand Corporation.

Darling-Hammond, L., \& Hudson, L. (1989). Teachers and teaching. In R. Shavelson, L. McDonnell, \& J. Oakes (Eds.), Indicators for monitoring mathematics and science education (pp. 66-95). Santa Monica, CA: Rand Corporation.

Darling-Hammond, L., \& Green, J. (1994). Teacher quality and equality. In P. Keating \& J. I. Goodlad (Eds.), Access to Knowledge. New York: College Entrance Examination Board.

Durkheim, E. (1961). Moral education: A study in the theory and application of the sociology of education, translated by E. K. Wilson and H. Schnurer. NewYork: Free Press.

Feistritzer, E. (1997). Alternative teacher certification: A state-by-state analysis (1997). Washington, DC: National Center for Education Information.

Gerald, D., \& Hussar, W. (1998). Projections of education statistics to 2008. Washington, DC: National Center for Education Statistics.

Goodlad, J. (1984). A place called school: Prospects for the future. St Louis: McGraw-Hill.

Grant, G. (1988). The world we created at Hamilton High. Cambridge, MA: Harvard University Press.

Granovetter, M. (1985). Economic action and social structure: The problem of embeddedness. American Journal of Sociology, 91, 481-510.

Grissmer, D., \& Kirby, S. (1987). Teacher attrition: The uphill climb to staff the nation's schools. Santa Monica, CA: Rand Corporation.

Grissmer, D., \& Kirby, S. (1992). Patterns of attrition among Indiana teachers, 1965-1987. Santa Monica, CA: Rand Corporation.

Grissmer, D., \& Kirby, S. (1997). Teacher turnover and teacher quality. Teachers College Record, 99, 45-56.

Guthrie, J. (1979). Organizational scale and school success. Educational Evaluation and Policy Analysis, 1, 17-27.

Hafner, A., \& Owings, J. (1991). Careers in teaching: Following members of the high school class of 1972 in and out of teaching (NCES Report No. 91-470). Washington, DC: U.S. Department of Education, National Center for Education Statistics.

Haggstrom, G. W., Darling-Hammond, L., \& Grissmer, D. (1988). Assessing teacher supply and demand. Santa Monica, CA: Rand Corporation.

Halaby, C., \& Weakliem, D. (1989). Worker control and attachment to the firm. American Journal of Sociology, 95, 549-591.

Heyns, B. (1988). Educational defectors: A first look at teacher attrition in the NLS72. Educational Researcher, 17, 24-32.

Hirschman, A. (1970). Exit, voice and loyalty. Cambridge: Harvard University Press. Hom, P., \& Griffeth, R. (1995). Employee turnover. Cincinnati: South-Western Publishing.

Ingersoll, R. (1993). Loosely coupled organizations revisited. Research in the Sociology of Organizations, 11, 81-112. 
Ingersoll, R. (1994). Organizational control in secondary schools. Harvard Educational Review, 64, 150-172.

Ingersoll, R. (1995a). Teacher supply, teacher qualitications and teacher turnover. Washington, DC: National Center for Education Statistics.

Ingersoll, R. (1995b). An agenda for research on teachers and schools: Revisiting NCES' schools and staffing survey. Washington, DC: National Center for Education Statistics.

Ingersoll, R. (1996). Teachers' decision-making power and school conflict. Sociology of Education, 69, 159-176.

Ingersoll, R. (1997). Teacher professionalization and teacher commitment: A multilevel analysis. Washington, DC: National Center for Education Statistics.

Ingersoll, R. (1999). The problem of underqualified teachers in American secondary schools. Educational Researcher, 28, 26-37.

Ingersoll, R. (2000a). Turnover among mathematics and science teachers. Washington, DC.: National Commission on Mathematics and Science Teaching for the 21st Century. (www.ed.gov/inits/Math/glenn/compapers.html).

Ingersoll, R. (2000b). Teacher Quality and Educational Inequality. Center for the Study of Teaching and Policy, University of Washington (under revision).

Ingersoll, R. (2000c). Teacher Shortages and Educational Inequality: an Organizational Analysis. (Manuscript submitted for publication).

Kalleberg, A., \& Mastekaasa, A. (1998). Organizational size, layoffs and quits in Norway. Social Forces, 76, 1243-73.

Kanter, R. (1977). Men and women of the corporation. New York: Basic.

Kirst, M. (1989). Who should control the schools? In T. J. Sergiovanni \& J. Moore (Eds.), Schooling for tomorrow. Boston: Allyn and Bacon.

Kopp, W. (1992). Reforming schools of education will not be enough. Yale Law and Policy Review, 10, 58-68.

Kozol, J. (1991). Savage inequalities. New York: Harper-Collins.

Likert, R. (1967). The human organization. New York: McGraw-Hill.

Lortie, D. (1975). School teacher. Chicago: University of Chicago Press.

March, J., \& Simon, H. (1958). Organizations. New York: Wiley.

Marso, R., \& Pigge, F. (1991). The impact of student transfers on teacher candidate quality. Education Review, 14, 19-32.

Mercer, W.M., (1999). Survey of registered nurse attraction and retention. Atlanta, GA: William M. Mercer, Inc.

Metz, M. (1986). Different by design. London: Routledge and Kegan Paul.

Miech, R., \& Elder, R. (1996). The service ethic and teaching. Sociology of Education, $69,237-253$.

Mobley, W. (1982). Employee turnover: Causes, consequences and control. Reading, MA: Addison-Wesley.

Mueller, C., \& Price, J. (1990). Economic, psychological and sociological determinants of voluntary turnover. Journal of Behavioral Economics, 19, 321-335. 
Murnane, R. (1981). Teacher mobility revisited. Journal of Human Resources, 16(1), 319.

Murnane, R. (1987). Understanding teacher attrition. Harvard Educational Review, 57(2), 177-182.

Murnane, R., Singer, J., \& Willett, J. (1988). The career paths of teachers: Implications for teacher supply and methodological lessons for research. Educational Researcher, 17(5), 22-30.

Murnane, R., Singer, J., Willett. J., Kemple, J., \& Olsen, R. (Eds.). (1991). Who will teach?: Policies that matter. Cambridge, MA: Harvard University Press.

National Academy of Sciences. (1987). Toward understanding teacher supply and demand. Washington, DC: National Academy Press.

National Commission on Excellence in Education. (1983). A nation at risk: The imperative for educational reform. Washington, DC: Government Printing Office.

National Commission on Teaching and America's Future. (1997). Doing what matters most: Investing in quality teaching. New York: NCTAF.

Newman, F., Rutter, R., \& Smith, M. (1989). Organizational factors that affect school sense of efficacy, community and expectations. Sociology of Education, 62, 221-38.

Oakes, J. (1990). Multiplying inequalities: The effects of race, social class, and tracking on opportunities to learn mathematics and science. Santa Monica, CA: The RAND Corporation.

Pallas, A. (1988). School climate in American high schools. Teachers College Record, $89,541-543$.

Parsons, Talcott. 1959. The school class as a social system: Some of its functions in American society. Harvard Educational Review 29:297-318.

Perrow, Charles. (1986). Complex organizations: A critical essay. New York: Random.

Pfeffer, J. (1982). Organizations and organization theory. Marshfield, MA: Pitman.

Porter, L. W., Lawler, E. E., \& Hackman, J. R. (1975). Behavior in organizations. New York: McGraw-Hill.

Price, J. (1977). The study of turnover. Ames, IA: Iowa State University Press.

Price, J. (1989). The impact of turnover on the organization. Work and Occupations, $16,461-473$

Price, J. (1997). Handbook of Organizational Measurement. International Journal of Manpower, 18: no. 4-6.

Reyes, P. (1990). Teachers and their workplace: Commitment, performance, productivity. Newbury Park, CA: Sage.

Rollefson, M., \& Broughman, S. (1995). Teacher supply in the United States: Sources of newly hired teachers in public and private schools, 1988-1991. Washington, DC: National Center for Education Statistics.

Rosenholtz, S. (1989). Teacher's workplace: The social organization of schools. New York: Longman.

Rosenholtz, S. (1985, January). Political myths about education reform: Lessons from research on teaching. Phi Delta Kappan, 349-355. 
Rowan, B., Raudenbush, S., \& Kang, S. J. (1991). Organizational design in high schools: A multilevel analysis. American Journal of Education, 99, 238-260.

Rumberger, R. (1987). The impact of salary differentials on teacher shortages and turnover: The case of mathematics and science teachers. Economics of Education Review, 6, 389-399.

Schlecty, P., \& Vance, V. (1981). Do academically able teachers leave education? The North Carolina case. Phi Delta Kappan, 63, 105-112.

Schlecty, P., \& Vance, V. (1983). Recruitment, selection and retention: The shape of the teaching force. Elementary School Journal, 83, 469-487.

Sclan, E. (1993). The effect of perceived workplace conditions on beginning teachers' work commitment, career choice commitment and planned retention. Ann Arbor, MI: University Microfilms International.

Snyder, T., Hoffman, C., \& Geddes, C. (1997). The Digest of Education. Washington, DC: U.S. Department of Education, National Center for Education Statistics.

Steers, R. M., \& Momday, R. T. (1981). Employee turnover and the post-decision accommodation process. In B. M. Shaw and L. L. Cummings (Eds.), Research in organizational behavior. Greenwich: JAI Press.

Theobald, N. (1990). An examination of the influence of personal, professional and school district characteristics on public school teacher retention. Economics of Education Review, 9, 241-250.

Turner, A. N., \& Lawrence, P. R. (1964). Industrial jobs and the worker. Cambridge, MA: Harvard University Press.

U.S. Bureau of the Census. (1998). Statistical abstract (117th Edition). Washington, DC: U.S. Department of Commerce.

Walberg, H., \& Walberg, H. (1994). Losing local control. Educational Researcher, 23(5), $19-26$.

Waller, W. (1932). The sociology of teaching. New York: Wiley.

Walton, R. E. (1980). Establishing and maintaining high commitment work systems. In J. Kimberly \& R. Miles (Eds.), The organization life cycle. San Francisco: JosseyBass.

Weiss, I. R., \& Boyd, S. E. (1990). Where are they now?: A follow-up study of the 1985-86 science and mathematics teaching force. Chapel Hill, NC: Horizon Research, Inc. 



\section{Center Affiliates}

American Association of Colleges of Teacher Education American Federation of Teachers

Council for Chief State School Officers

National Alliance of Business

National Association of Secondary School Principals

National Board for Professional Teaching Standards

National Council for Accreditation of Teacher Education

National Council of Teachers of English

National Education Association

National School Boards Association

National Staff Development Council

National Urban League

\section{Center Team}

Principal Investigators and Co-Principal Investigators

\section{UNIVERSITY OF WASHINGTON}

Michael Knapp, Center Director

James Banks

Margaret Plecki

Sheila Valencia

\section{STANFORD UNIVERSITY}

Linda Darling-Hammond

Pamela Grossman

Milbrey McLaughlin

Joan Talbert

\section{UNIVERSITY OF MICHIGAN}

Deborah Loewenberg Ball

David Cohen

Edward Silver

\section{UNIVERSITY OF PENNSYLVANIA}

Thomas Corcoran

Richard Ingersoll

\section{Researchers at Other Institutions}

Barnett Berry, University of North Carolina

David Monk, Pennsylvania State University

Jon Snyder, University of California at Santa Barbara

Judy Swanson, Education Matters, Inc.

Suzanne Wilson, Michigan State University
American Association of School Administrators Association for Supervision and Curriculum Development International Reading Association

National Association of Elementary School Principals

National Association of State Boards of Education

National Conference of State Legislatures

National Council for the Social Studies

National Council of Teachers of Mathematics

National Governors' Association

National Science Teachers Association

National Urban Coalition

Teachers Union Reform Network

\section{Contact Information}

Michael S. Knapp, Center Director Miller Hall M201, College of Education

University of Washington, Box 353600

Seattle, WA 98195-3600

email:mknapp@u.washington.edu

Michele C. Ferguson, Center Manager Miller Hall 203C, College of Education University of Washington, Box 353600 Seattle, WA 98195-3600

Phone: (206) 221-4114

FAX: (206) 616-6762

email: ctpmail@u.washington.edu

Sally Brown, Communications Director Miller Hall 404B, College of Education University of Washington, Box 353600 Seattle, WA 98195-3600

Phone: (206) 543-5319

FAX: (206) 616-6762

email: salbrown@u.washington.edu

Web Address

http://www.ctpweb.org 
